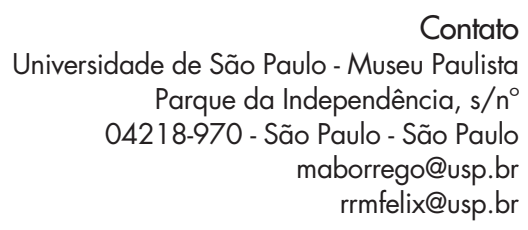

Contato

Universidade de São Paulo - Museu Paulista Parque da Independência, $\mathrm{s} / \mathrm{n}^{\circ}$ 042 1 8-970 - São Paulo - São Paulo maborrego@usp.br rrmfelix@usp.br

\title{
AMBIENTES DOMÉSTICOS E DINÂMICAS SOCIAIS EM SÃO PAULO COLONIAL
}

\section{Maria Aparecida de Menezes Borrego**}

Universidade de São Paulo

São Paulo - São Paulo - Brasil Rogério Ricciluca Matiello Félix ${ }^{* * *}$

Universidade de São Paulo

São Paulo - São Paulo - Brasil

\section{Resumo}

A proposta do artigo é analisar a dimensão material da vida social dos grupos intermédios residentes na cidade de São Paulo ao longo do Setecentos ligados ao comércio. Para tanto, partimos do pressuposto de que os atributos físicos de peças de mobiliário informam não apenas sobre a função utilitária do objeto, mas, antes, seus usos indicam a reiteração e/ou transformação de padrões de conduta e de hierarquias familiar e social. Para desenvolver o argumento, primeiramente teceremos breves comentários sobre o espaço doméstico na cidade de São Paulo durante o século XVIII. Em seguida, nos deteremos na análise do uso social de alguns móveis nos interiores das moradas de setores mercantis, relacionando sua existência com as mudanças socioeconômicas pelas quais passava a capital, graças às atividades comerciais que se desenvolviam na região paulista em razão do abastecimento das áreas mineratórias de Minas Gerais, Goiás e Cuiabá.

\section{Palavras-chave}

Espaço doméstico - mobiliário - grupo mercantil - São Paulo.

* Pesquisa realizada com apoio da Fundação de Apoio à Pesquisa do Estado de São Paulo Fapesp, modalidade Jovem Pesquisador (2011-2014).

${ }^{* *}$ Historiadora, docente do Departamento de Acervo e Curadoria do Museu Paulista e do Programa de Pós-graduação em História Social da Faculdade de Filosofia, Letras e Ciências Humanas.

${ }^{* * *}$ Mestrando em História Social pela Faculdade de Filosofia, Letras e Ciências Humanas da Universidade de São Paulo. Bolsista Capes. 


\author{
ulista \\ Parque da Independência, $\mathrm{s} / \mathrm{n}^{\circ}$ \\ 042 1 8-970 - São Paulo - São Paulo \\ maborrego@usp.br \\ rrmfelix@usp.br
}

\section{DOMESTIC}

ENVIRONMENTS

AND SOCIAL

DYNAMICS IN

COLONIAL SÃO

PAULO

\section{Maria Aparecida de Menezes Borrego}

Universidade de São Paulo

São Paulo - São Paulo - Brasil

Rogério Ricciluca Matiello Félix

Universidade de São Paulo

São Paulo - São Paulo - Brasil

\begin{abstract}
This article proposes to analyze the material dimension of the social life of intermediate groups living in the city of São Paulo during the 18th century and dealing with trade. Therefore, we assume that the physical attributes of pieces of furniture not only inform about the utilitarian function of the object, but rather its uses indicate the reiteration and / or transformation of patterns of behavior and of family and social hierarchies. To develop the argument, first we will weave brief comments on the domestic space in São Paulo during the 18th century. Then we will concentrate on the analysis of the social use of some furniture in the interiors of commercial sectors houses, relating their existence with the socioeconomic changes the capital underwent due to the commercial activities that developed in São Paulo region because of the supply of mining areas of Minas Gerais, Goiás and Cuiabá.
\end{abstract}

\title{
Keywords
}

Domestic space - furniture - trade group - São Paulo. 
Maria Aparecida de Menezes Borrego \& Rogério Ricciluca Matiello Félix

Ambientes domésticos e dinâmicas sociais em São Paulo colonial

\section{Introdução}

Já é senso comum na historiografia brasileira a afirmação de que o mobiliário nas casas de morada coloniais estava restrito ao necessário, muitas vezes contrastando com a fortuna de seus proprietários, assentada principalmente sobre propriedades imobiliárias, dinheiro, joias e escravos. ${ }^{1}$

Para entender tal escassez de móveis, desvinculando-a da noção de pobreza atribuída aos interiores domésticos e à própria condição econômica dos habitantes - interpretação arraigada nos estudos sobre espaço doméstico colonial -, temos que levar em conta, como bem o fez Leila Mezan Algranti, que, durante os primeiros séculos de colonização, o espaço de sociabilidade para a maior parte da população se concentrava fora das paredes do domicílio, fosse ele a rua ou a igreja, uma vez que os grandes momentos de interação social eram as festas religiosas. ${ }^{2}$

A afirmação do status da família se fazia, então, nestes momentos públicos de congraçamento social, por meio do lugar ocupado nas festividades, dos trajes "de festa", do séquito de escravos. Eram estes os principais sinais exteriores de riqueza e distinção social. Como o lazer doméstico se dava, sobretudo, no mundo exterior, Vânia Carvalho comenta que a vida doméstica fora marcada por comportamentos e formas de mediação material pouco hierarquizadas e pouco ostensivas. ${ }^{3}$

Entretanto, na passagem do século XVIII para o XIX, como sugere Nuno Madureira para o contexto lisboeta, já é possível detectar mudanças nos padrões de interação social nas cidades, com a procura cada vez maior de recintos fechados para formas de convivência em detrimento dos espaços abertos. Ao aproximar os corpos, tal movimento converteu o campo de observação visual mais individualizado, obrigando a gestos e palavras mais regradas. ${ }^{4}$ Nesses ambientes domésticos, tornou-se cada vez mais comum a existência de um referente alimentar que servia de elemento articulador

\footnotetext{
FLEXOR, Maria Helena Ochi. Mobiliário baiano. Brasília,DF:Iphan/Programa Monumenta,2009, p. 18-9.

2 ALGRANTI, Leila Mezan. Famílias e vida doméstica. In: SOUZA, Laura de Mello e. História da vida privada no Brasil, v. 1. São Paulo: Companhia das Letras, 1997, p. 113.

3 CARVALHO, Vânia Carneiro de. Gênero e artefato: o sistema doméstico na perspectiva da cultura material: São Paulo, 1870-1920. São Paulo: Edusp, 2008, p. 165.

${ }_{4}$ MADUREIRA, Nuno Luís. Luxo e distinção: 1750-1830. Lisboa: Editorial Fragmentos, 1990, p. 76.
} 
Maria Aparecida de Menezes Borrego \& Rogério Ricciluca Matiello Félix

Ambientes domésticos e dinâmicas sociais em São Paulo colonial

entre os participantes das reuniões promovidas, como assinalou Maria de los Angeles Perez Samper para a Barcelona setecentista. ${ }^{5}$

Para o universo inglês, a interiorização das sociabilidades pode ser antecipada para a primeira metade do século XVIII, capitaneada pelo grupo mercantil, como mostrou Lorna Weatherill, a partir de uma análise detalhada sobre a quantidade de bens domésticos arrolados em inventários post mortem. ${ }^{6}$ Por sua vez, partindo sobretudo da leitura de diários, livros de contabilidade de casais e autos crimes, Amanda Vickery mostrou os múltiplos papéis assumidos pelos artefatos e a configuração de espaços de privacidades tanto nas casas das elites do interior como nos aposentos alugados da Londres industrial. ${ }^{7}$

Para as sociabilidades que se desenvolviam nas residências da elite francesa no Antigo Regime, são instigantes e inspiradores para esse artigo os trabalhos de Mimi Hellman, Dena Goodman e Carolyn Sargentson, por analisarem as práticas sociais configuradas pelo uso de determinados móveis, decorrentes da relação corpo-objeto. ${ }^{8}$

Sobre as transformações sociais que se processavam nos interiores domésticos na América portuguesa, Algranti assinala que, desde os inícios do Oitocentos, “a festa pública, organizada pelas municipalidades e pelas pa-

5 PEREZ SAMPER, María de los Ángeles. Espacios e prácticas de sociabilidad en el siglo XVIII: tertulias, refrescos y cafés de Barcelona. Cuadernos de Historia Moderna, n. 26, 2001, p. 11-55.

6 WEATHERILL, Lorna. Consumer behaviour and material culture in Britain, 1660-1760. Londres; Nova York: Routledge, 1988.

7 VICKERY, Amanda. An Englishman's home is his castle? Thereholds, boundaries and privacies in the eighteenth-century London house. Past and Present, 199, May 2008, p. 147-173; Idem. His and hers. In Idem. Behind closed doors: At home in Georgian England. New Haven, Londres: Yale University Press, 2009, p. 106-128; Idem. The gentleman's daughter: Women's lives in Georgian England. New Haven, Londres: Yale University Press, 2003. Debruçado sobre os autos-crimes de Old Bailey, John Styles problematizou as noções de consumo do século XVIII como o terreno da expansão da escolha individual e conjeturou sobre os grupos responsáveis pela conformação do gosto e sua difusão numa sociedade multifacetada como aquela que emergia dos processos judiciais. STYLES, John. Loading at the Old Bailey: Lodgings and their furnishing in eighteenthcentury London. In: STYLES, John \& VICKERY, Amanda (ed.). Gender, taste and material culture in Britain and North America, 1700-1830. New Haven; Londres: Yale Center of British Art; Paul Mellon Centre for Studies of British Art, 2006, p. 61-80.

${ }^{8}$ HELLMAN, Mimi. Furniture, sociability, and the work of leisure in eighteenth-century France. Eighteenth-century Studies, vol. 32, n. 4, 1999, p. 415-445; GOODMAN, Dena. The secrétaire and the integration of the eighteenth-century self. In: GOODMAN, Dena \& NORBERG, Kathryn (org.). Furnishing the eighteenth century: what furniture can tell us about European and American past. Nova York; Londres: Routledge, 2007, p. 183-204; SARGENTSON, Carolyn. Looking at furniture inside out: Strategies of secrecy and security in eighteenth-century French furniture. In Idem, ibidem, p. 205-236. 
Maria Aparecida de Menezes Borrego \& Rogério Ricciluca Matiello Félix

Ambientes domésticos e dinâmicas sociais em Sc̃o Paulo colonial

róquias, continuava muitas vezes dentro da casa, principalmente entre os membros da elite que organizavam banquetes, cantorias e jogos". Problematizando a questão, Vânia Carvalho argumenta que "o dinamismo dos relacionamentos sociais e da vida urbana conjugados à heterogeneidade crescente das elites e aos novos segmentos em ascensão exigiam uma vida social mais intensa, engajando a casa nessa nova rotina de encontros".10

A casa deixa de ser tão somente local de abrigo e trabalho para se tornar lentamente também um espaço de sociabilidades. Os interiores domésticos passam então a contar com novas salas de recepção destinadas a momentos de convívio com pessoas alheias ao núcleo familiar e, como decorrência deste fenômeno, o despojamento material gradualmente cede espaço à entrada de mais móveis nos aposentos, que eram confeccionados "não apenas para conter e suportar, mas ainda para serem vistos".11

Quando se volta o olhar para a realidade setecentista paulista, quais são os vestígios materiais e/ou os indícios textuais sobre o espaço doméstico e o processo de desenvolvimento de relações pessoais intramuros?

Nas residências paulistanas, as unidades de trabalho e moradia funcionavam juntas, em plantas estreitas e alongadas. Os sobrados propriamente ditos, de dois pavimentos, são escassos na cidade de São Paulo até fins do século XVIII, onde predominavam as casas térreas e os chamados "falsos" sobrados de taipa de pilão. Os falsos sobrados ou casas assobradadas designavam construções cujos sótãos teriam aberturas situadas sob os beirais, destinados à estocagem de grãos ou ao dormitório dos escravos. ${ }^{12}$

As atuações relativas ao convívio com estranhos tinham lugar nos cômodos que davam para a rua, os quais serviam para "agasalhar visitas" ou se prestavam ao comércio de secos, molhados e/ou de artefatos produzidos por artesãos. As relações familiares e pessoais bem como os afazeres domésticos se desenvolviam no corpo da casa, nas alcovas, varandas - voltadas para o fundo dos terrenos - e nos quintais, onde se encontravam edificadas as co-

\footnotetext{
9 ALGRANTI, Leila Mezan, op. cit., p. 118.

${ }^{10}$ CARVALHO, Vânia Carneiro de, op. cit., 2008, p. 165.

${ }^{11}$ SUANO, Marlene. Alfaias, apetrechos, tarecos, trecos: os móveis. In: MENESES, Ulpiano T. Bezerra de (org.). Como explorar um museu histórico. São Paulo: Museu Paulista/USP, 1992, p. 16.

${ }^{12}$ Como bem explicou Carlos Lemos, "sobrado" não necessariamente indicava dois andares, mas antes correspondia ao espaço que sobrou, tanto acima do teto - sótão - como abaixo do soalho - o porão. Cf. LEMOS, Carlos Alberto. Casa paulista: história das moradias anteriores ao ecletismo trazido pelo café. São Paulo: Edusp, 1999, p. 25.
} 
Maria Aparecida de Menezes Borrego \& Rogério Ricciluca Matiello Félix

Ambientes domésticos e dinâmicas sociais em São Paulo colonial

zinhas ao lado de pequenas criações de animais e plantações de hortaliças e árvores frutíferas.

Nos inventários post-mortem, embora as descrições dos imóveis dos inventariados auxiliem a espacializar tais atividades, estas nem sempre deixam claras as plantas das moradias. Invariavelmente são registradas pelo número de lanços que, segundo Carlos Lemos, correspondiam a uma série de cômodos encarreirados, um atrás do outro, formando uma fila perpendicular à rua. O elemento que unia os lanços era o corredor, passagem estreita e comprida situada entre os compartimentos. Havia também o chamado "corredor de trás" - onde normalmente se instalava o fogão -, paralelo à rua nos fundos da casa, separando os cômodos dos quintais já murados no século XVIII.13

Eram em moradas semelhantes às descritas que residiam os agentes mercantis reinóis que foram se fixando em solo paulistano desde inícios do século XVIII, atraídos pelos negócios decorrentes das descobertas auríferas. No entanto, antes de se estabelecerem na capital paulista, alguns permaneciam temporariamente na cidade do Rio de Janeiro, enquanto outros percorriam as localidades da região centro-sul da colônia, onde eram introduzidos na carreira mercantil, conduzindo tropas, fazendo cobranças e vendendo mercadorias.

Uma vez residentes na cidade de São Paulo, ${ }^{14}$ tais sujeitos passavam a se dedicar a múltiplas atividades econômicas - lojas de fazenda seca, vendas, emprego de negros de ganho, comércio de escravos e animais, aluguel de imóveis, empréstimo de dinheiro a juros e envio de carregações a Cuiabá e Goiás. ${ }^{15}$ No plano sociopolítico, muitos buscaram ocupar cargos nos órgãos de poder local - câmara municipal, companhia de ordenanças, irmandades - e nas instituições dignificadoras do Império - Santo Ofício e Ordem de Cristo -, a fim de conquistarem prestígio e reconhecimento social.

\footnotetext{
${ }^{15}$ Para uma descrição mais pormenorizada dos programas de necessidades das residências coloniais paulistas, ver LEMOS, Carlos, op. cit. e CARVALHO, Vânia Carneiro de, op. cit., 2008.

${ }^{14}$ Os mais afortunados tinham preferência pela área central da capital, o chamado Triângulo, formado pelas ruas Direita, São Bento e Rosário, tendo como "vértices" os templos religiosos de São Francisco, São Bento e Carmo e, invariavelmente, residiam em moradas de taipa de pilão.

${ }^{15}$ Sobre o processo de formação e enriquecimento dos grupos intermédios ligados às transações mercantis na cidade de São Paulo, ver BORREGO, Maria Aparecida de Menezes. A teia mercantil: negócios e poderes em São Paulo colonial (1711-1765). São Paulo: Alameda/ Fapesp, 2010. Sobre o comércio com as regiões mineradoras de Cuiabá e Goiás, ver Sérgio Buarque de Holanda, Caminhos e fronteiras, Monções e Extremo Oeste, sendo estas duas últimas obras recentemente relançadas. Ver HOLANDA, Sérgio Buarque de. Monções e Capítulos da expansão paulista. Organização de Laura de Mello e Souza e André Sekkel de Cerqueira. Notas de André Sekkel de Cerqueira. São Paulo: Companhia das Letras, 2014.
} 
Maria Aparecida de Menezes Borrego \& Rogério Ricciluca Matiello Félix

Ambientes domésticos e dinâmicas sociais em São Paulo colonial

Para esse estudo foram selecionados 30 agentes mercantis atuantes na cidade de São Paulo, cujos inventários - ou de suas esposas - foram abertos entre as décadas de 1730 e 1790 e estão depositados no Arquivo Público do Estado de São Paulo e no Arquivo do Tribunal de Justiça do Estado de São Paulo. ${ }^{16}$ Tal segmento mais restrito era marcado por uma profunda desigualdade econômica entre seus membros, cujos patrimônios líquidos variavam entre 167\$806 (cento e sessenta e sete mil, oitocentos e seis réis) e 61:728\$713 (sessenta e um contos, setecentos e vinte e oito mil e setecentos e treze réis), pertencentes respectivamente a Bento do Amaral Silva, falecido em 1753, e Gaspar de Matos, cujo processo fora aberto em $1735 .{ }^{17}$

Se, por um lado, os mais enriquecidos poderiam ser caracterizados, em termos de riqueza, como elites locais, por outro, na hierarquia sociopolítica do Império português, tais agentes comerciais se enquadravam como grupos intermédios, pois que desfrutavam de acesso limitado a cargos, patentes, mercês e títulos nobiliárquicos. ${ }^{18}$

A fixação de lojas e residência em solo urbano, portanto, concorreu, de forma preponderante, para a modificação da paisagem física e humana da capital ao longo do século XVIII. Enquanto os proprietários da centúria anterior analisados por Alcântara Machado moravam preferencialmente em chácaras e sítios e só se deslocavam à vila quando tinham negócios a fazer, ${ }^{19}$ ricos habitantes do Setecentos residiam na área urbana - mas também possuíam imóveis nas cercanias da cidade -, não mais considerada como um apêndice do campo, mas, sim, como um centro mercantil em desenvolvimento, favorável às possibilidades de ascensão social, às alianças matrimoniais e à participação nas instituições de prestígio.

\footnotetext{
${ }^{16}$ Tais processos foram os únicos encontrados para uma amostra maior de 100 agentes mercantis que haviam participado dos órgãos de poder local até 1765. A discrepância entre o número de inventariados e de falecidos provavelmente se deve ao extravio dos documentos ao longo dos séculos. Entretanto, há que se destacar que os inventários não eram obrigatórios em todos os casos de morte no Império português, mas, sim, eram abertos quando existiam órfãos menores e bens a serem partilhados.

${ }^{17}$ Ver arrolamento de inventários nas fontes.

${ }^{18}$ Sobre a plasticidade do conceito de grupos intermédios e os múltiplos significados por ele assumidos no Portugal moderno, ver DURÃES, Andreia. Grupos intermédios em Portugal (16001850): uma aproximação ao vocabulário social. Topoi, vol. 14, n. 27, Rio de Janeiro, 2013, p. 318343. Sobre o desdobramento e emprego do conceito no Império lusitano, conferir, neste dossiê, o artigo de OLIVAL, Fernanda $\mathcal{E}$ RODRIGUES, Aldair Carlos. Reinóis v. naturais nas disputas pelos lugares eclesiásticos do Atlântico português: aspectos sociais e políticos (século XVIII).

${ }^{19}$ MACHADO, Alcântara. Vida e morte do bandeirante. Belo Horizonte: Itatiaia; São Paulo: Edusp, 1980.
} 
Maria Aparecida de Menezes Borrego \& Rogério Ricciluca Matiello Félix

Ambientes domésticos e dinâmicas sociais em São Paulo colonial

Conforme os estudos pioneiros de Maria Luiza Marcílio, a cidade de São Paulo vivenciou um aumento demográfico contínuo no século XVIII, contando com um importante setor mercantil na composição da população. ${ }^{20}$ Quando da restauração da capitania e elaboração do primeiro censo da cidade de São Paulo, em 1765, membros do grupo mercantil se situavam no mais elevado patamar da sociedade paulistana, que contava com cerca de 20 mil habitantes. ${ }^{21}$

De acordo com os resultados alcançados em pesquisa de doutorado, teriam sido eles os protagonistas da dinamização da realidade socioeconômica paulistana ao longo do século XVIII, muito em função das transações comerciais de abastecimento de Cuiabá e Goiás, mesmo durante o período de perda da autonomia da capitania de São Paulo (1748-1765). Ademais, avaliou-se a mobilidade social de membros do setor mercantil não só em termos econômicos, por meio dos patrimônios declarados nos maços de população e registrados nos inventários post-mortem, mas, sobretudo, pelo capital simbólico acumulado pela participação em órgãos de poder.

Se, naquela investigação, as marcas distintivas que os comerciantes traziam e ostentavam por serem camaristas, irmãos de ordens terceiras e da Santa Casa de Misericórdia, oficiais das companhias de ordenanças, familiares do Santo Ofício e cavaleiros da Ordem de Cristo foram consideradas estratégias para o reforço do sentimento de pertença ao Império português, no presente estudo, a posse de artefatos domésticos será tomada como mais um recurso a ser mobilizado para reconhecimento social numa sociedade escravista com traços de Antigo Regime. ${ }^{22}$

Por meio do recheio dos interiores domésticos paulistas intenta-se avaliar a inserção da capitania no conjunto do Império e, por outro lado, as especificidades locais.

Além disso, busca-se desenvolver a hipótese de que os agentes comerciais teriam sido os responsáveis pela difusão de novos comportamentos nas casas coloniais por meio da introdução de peças de mobiliário e/ou da

\footnotetext{
${ }^{20}$ MARCÍLIO, Maria Luiza. A cidade de São Paulo. Povoamento e população. 1750-1850. São Paulo: Pioneira/Edusp, 1974; Idem. Crescimento demográfico e evolução agrária paulista - 1700-1836. São Paulo: Hucitec/Edusp, 2000.

${ }^{21}$ Os cabedais do grupo mercantil correspondiam a cerca de $45 \%$ de toda a riqueza declarada. Cf. Censo de 1765. In: Documentos interessantes para a história e costumes de S. Paulo, vol. 62. São Paulo: Instituto Historico e Geographico de S. Paulo, 1937.

${ }^{22}$ Sobre a caracterização da sociedade colonial, ver BORREGO, Maria Aparecida de Menezes, op. cit., 2010, p. 135-140.
} 
Maria Aparecida de Menezes Borrego \& Rogério Ricciluca Matiello Félix

Ambientes domésticos e dinâmicas sociais em Sc̃o Paulo colonial

modificação de seus atributos físicos. ${ }^{23}$ Ainda que de forma incipiente, tais transformações antecipam o início do processo de interiorização das sociabilidades para meados do século XVIII e reforçam o argumento da liderança desse segmento intermédio no desenvolvimento econômico da cidade antes do governo do morgado de Mateus (1765-1775) e intensificado sob seus auspícios. A evidência é ainda maior quando se comparam os bens domésticos dos agentes mercantis aos de indivíduos de outros segmentos sociais, ligados à agricultura, ofícios mecânicos e artes liberais, em termos de atributos físicos, de valores e de quantidades.

Para tanto, procuramos atentar para os atributos físicos das peças de mobiliário, descritas nos inventários e visíveis nos remanescentes tridimensionais de acervos museológicos, tendo no horizonte o paradigma indiciário arqueologicamente (des)construído por Carlo Ginzburg. ${ }^{24}$ Eleger as características materiais desses artefatos como itens de observação e comparação incita à reflexão sobre o papel dos objetos - quando em uso pelos indivíduos - como mediadores de relações humanas e conformadores de práticas sociais, indo além da mera concepção dos objetos como produtos do trabalho de uma dada sociedade. ${ }^{25}$

Pretende-se, portanto, a partir de agora, refletir sobre a dimensão material da realidade social da cidade de São Paulo ${ }^{26}$ no século XVIII, tendo como plataformas privilegiadas de observação as peças de mobiliário de assento, suporte e repouso que compunham os interiores domésticos dos grupos intermédios ligados às atividades comerciais. ${ }^{27}$

\footnotetext{
${ }^{23}$ Sobre a questão da imitação/ emulação/ distinção social, ver a discussão realizada por Amanda Vickery acerca das teorias de Thorstein Veblen, Pierre Bourdieu e Daniel Miller. VICKERY, Amanda. Women and the world of goods: a Lancashire consumer and her possessions, 1751-81. In: BREWER, John $\&$ PORTER, Roy. Consumption and the world of things. Londres: Routledge, 1994, p. 274-301.

${ }^{24}$ GINZBURG, Carlo. Sinais: Raízes de um paradigma indiciário. In: Idem. Mitos, emblemas, sinais: morfologia e história. São Paulo: Companhia das Letras, 1989, p. 143-179.

${ }^{25}$ Sobre as dimensões do artefato, ver MENESES, Ulpiano Toledo Bezerra de. A cultura material no estudo das sociedades antigas. Revista de História, n. 115, São Paulo, 1983, p. 103-117; Idem. Rumo a uma "história visual". In: MARTINS, José de Souza; ECKERT, Cornelia; NOVAES, Sylvia Caiuby. O imaginário e o poético nas Ciências Sociais. Bragança Paulista: Edusc, 2005, p. 33-56.

${ }^{26}$ Acerca da dimensão material da realidade social, ver ainda MENESES, Ulpiano Toledo Bezerra de. Fontes textuais, cultura visual, história visual. Balanço provisório, propostas cautelares. Revista Brasileira de História, vol. 23, n. 45, São Paulo, 2003, p. 11-36.

${ }^{27}$ A divisão proposta para as peças de mobiliário assenta-se na classificação adotada pelo Serviço de Objetos do Museu Paulista - USP. Cf. PAIXÃO, Giselle Marques Leite. Sistema descritivo para acervos de mobiliário, contendo 923 vocábulos e 638 ilustrações. In: BARBUY, Heloisa (org.). Instrumento para catalogação produzido para o Serviço de Objetos do Museu Paulista-USP. São Paulo:
} 


\section{Os interiores domésticos do grupo mercantil}

Os bens domésticos possuídos pelos agentes mercantis inventariados foram comparados aos de 39 inventariados de São Paulo de estratos sociais diferentes - agricultores, oficiais mecânicos, membros da elite agrária -, cujos processos foram abertos no mesmo período, e a 24 outros habitantes da cidade paulistana, cujos inventários datam de 1801 a 1840, período considerado pela historiografia como o inaugural da interiorização das sociabilidades no contexto paulista.

Os meados dos Setecentos foram privilegiados justamente por corresponderem ao período de intensas trocas comerciais entre esses sujeitos e as regiões mineratórias de Cuiabá, cujas minas foram descobertas em 1718, e de Goiás, cujos descobrimentos auríferos remontam a 1725.

Durante o governo do morgado de Mateus e nos anos subsequentes, muitos mercadores diversificaram ainda mais suas atividades econômicas, beneficiados pela produção e/ou comercialização do açúcar, que passou a ser estimulado para exportação na capitania de São Paulo. Entretanto, estas últimas atividades não são aqui reconhecidas como propulsoras do desenvolvimento econômico da capital paulista, antes tributário das realizações mercantis referidas, que articulavam a cidade a outras regiões coloniais.

Uma primeira avaliação sobre o conjunto de peças de mobiliário existentes nas casas paulistanas da amostra selecionada já revela que os agentes mercantis eram os maiores detentores de móveis, ${ }^{28}$ sugerindo que a fixação em solo urbano e a sedimentação dos negócios levaram a um incremento do espaço doméstico cada vez mais mobiliado e frequentado.

\section{a. Sociabilidades}

A circulação pelos recintos, a acomodação dos residentes do domicílio, a recepção a pessoas alheias ao fogo - membros da família, vizinhos, parceiros comerciais - levam-nos a avaliar o papel dos móveis de assento na intermediação das relações sociais. De acordo com a documentação, esse tipo de mobiliário era o mais numeroso nos ambientes domésticos de agentes

MP-USP, 1999. Os móveis de guarda - caixas, arcas, canastras, cômodas, contadores, armários - já foram objetos de análise de outros estudos.

${ }^{28}$ Em comparação à posse de artefatos domésticos por agricultores, artífices, artistas, boticários, membros da elite agrária. 
Maria Aparecida de Menezes Borrego \& Rogério Ricciluca Matiello Félix

Ambientes domésticos e dinâmicas sociais em Sc̃o Paulo colonial

mercantis em São Paulo setecentista, fornecendo indícios sobre as sociabilidades desenvolvidas em salas de recepção.

Para ocontexto português, Fernanda Olivalencontrou situaçãosemelhante para as casas da aristocracia, na segunda metadedo séculoXVIII, diferentemente da realidade das casas populares, onde predominavam caixas, arcas e baús. ${ }^{29}$

Entretanto, não podemos esquecer que, no Brasil, até o século XIX, as mulheres sentavam-se à maneira asiática sobre o chão de terra batida, sobre a esteira, a rede, sobre o assento duro de marquesas. ${ }^{30}$ De origem árabe, o costume de se sentar sobre estrados, enraizado na península Ibérica, foi transplantado para a América e, sobre esses tabuados, colocados junto às paredes, trabalhava-se durante o dia e, por vezes, à noite, arrumava-se a cama. ${ }^{31}$

Na cidade de São Paulo, embora fosse comum a ocorrência de um estrado por domicílio, alguns comerciantes eram detentores de mais peças, cujas dimensões em geral variavam de 7 a 12 palmos de comprimento por 4 a 5 palmos de largura, comportando uma ou mais pessoas acomodadas no mesmo espaço. Para que se tenha ideia, o homem de negócio Francisco Pereira Mendes, falecido na década de 1780, possuía quatro estrados e 28 móveis de assento, distribuídos entre a casa da cidade e o sítio. ${ }^{32}$ Da mesma forma, Escolástica Veloso, esposa do mercador Thomé Rabelo Pinto, cujo inventário fora aberto em 1753, detinha três estrados e 21 móveis de assento.

Saindo do chão, localizamos variados móveis de assento individuais e coletivos, que correspondem a cadeiras, tamboretes, poltronas, mochos, bancos e escabelos.

Ao nos debruçarmos sobre os inventários das décadas de 1730 a 1790 à procura de cadeiras, nos deparamos com pouquíssimas peças, mesmo entre os proprietários mais abastados. Para o grupo dos não comerciantes, encontramos menção a cadeiras apenas em dois processos. No inventário de Manuel de Gois Cardoso e de sua mulher Isabel de Almeida, moradores no bairro de

\footnotetext{
${ }^{29}$ OLIVAL, Fernanda. Os lugares e espaços do privado nos grupos populares e intermédios. In:MONTEIRO, Nuno Gonçalo (org.). História da vida privada em Portugal, vol. 2. Lisboa: Círculo de Leitores, 2011, p. 254.

${ }^{30}$ CARVALHO, Vânia Carneiro de, op. cit., 2008, p. 199.

${ }^{31}$ Ver FLEXOR, Maria Helena, op. cit., 2009. Era ainda sobre o estrado que os mortos poderiam ser velados, como evidencia o desejo do comerciante Jerônimo de Castro Guimarães, em seu testamento, datado de 1797: "meu corpo será amortalhado no hábito de meu Patrono São Francisco e posto na minha sala em um estrado e tapete que tenho com quatro velas no corpo e outras quatro ao pé da imagem do Santo Cristo chamada de meia libra e do mesmo estrado será levado na tumba da Santa Casa".

32 Devido ao grande número de excertos retirados da documentação, para que não se repetissem exaustivamente, decidiu-se alocar as referências às fontes primárias em listagem ao final do artigo.
} 
Maria Aparecida de Menezes Borrego \& Rogério Ricciluca Matiello Félix

Ambientes domésticos e dinâmicas sociais em São Paulo colonial

Santa Ana, aberto em 1744, temos seis cadeiras, tão somente descritas como "de pau", provavelmente colocadas à volta da mesa de sete palmos que as precede na avaliação dos bens. E no testamento de José de Gois e Morais, datado de 1735, igual e parcamente descritas, temos "seis cadeiras de bom uso".

O que teria acontecido com as 1.005 cadeiras contabilizadas por Ernani da Silva Bruno em 188 espólios abertos a partir de 1594 até inícios do século XVIII, foi a primeira questão levantada. ${ }^{33}$

Um olhar mais atento, entretanto, revelou que se não havia menção a cadeiras nos inventários dos agentes mercantis e/ou de suas esposas, nas décadas de 1730, 1740, 1750 e 1770, havia o registro de mais de duas centenas de tamboretes, a princípio considerados pelos especialistas como cadeiras rasas sem braços nem espaldar. Entretanto, flagramos a descrição de tamboretes com encosto, como os apresentados a seguir.

No inventário do homem de negócios Gaspar de Matos, aberto em 1735, temos "doze tamboretes da moda de encosto com pregadura dourada grossa feitos na Bahia em bom uso"; no do mercador Agostinho Duarte do Rego, aberto em 1752, lemos "seis tamboretes de encosto e pregaria grossa"; e, no processo de Escolástica Veloso, esposa do agente mercantil Thomé Rabelo Pinto, aberto no ano seguinte, encontramos "sete tamboretes com assento e encosto de couro lavrado com pregaria grossa e dourada em meio uso". Por fim, no inventário do negociante José da Silva Ferrão, aberto em 1762, foram registrados 25 tamboretes, dos quais "doze grandes, de encosto, com pregaria dourada".

Aventamos então a hipótese de que tamborete com encosto fosse a designação genérica dada à cadeira de sola no século XVIII em São Paulo. Tal hipótese foi confirmada por Maria Helena Flexor no trabalho seminal sobre o mobiliário baiano e por João Filipe da Silva Nascimento, estudioso das cadeiras portuguesas. ${ }^{34} \mathrm{O}$ termo cadeira voltaria a público mais enfaticamente a partir dos anos 1770, para preponderar nas primeiras décadas dos Oitocentos nas casas da elite.

As cadeiras de sola, pesadas e robustas, eram, em geral, destinadas à posição rígida e definida, sem muita flexibilidade para movimentação. ${ }^{35}$ Dispostas junto às paredes, exigiam posturas físicas mais protocolares e não

\footnotetext{
${ }^{33}$ Referência a BRUNO, Ernani da Silva. O equipamento da casa bandeirista segundo os antigos inventários e testamentos. São Paulo: Departamento do Patrimônio Histórico, 1977.

${ }^{34}$ FLEXOR, Maria Helena, op. cit., 2009; PINTO, Augusto Cardoso \& NASCIMENTO, João Felipe da Silva. Cadeiras portuguesas. Lisboa: Ed. dos autores, 1952.

${ }^{35}$ Para se ter uma ideia, as cadeiras de sola do Museu Paulista pesam entre 6,700 kg e 8,100 kg.
} 
Maria Aparecida de Menezes Borrego \& Rogério Ricciluca Matiello Félix

Ambientes domésticos e dinâmicas sociais em Sc̃o Paulo colonial

estimulavam situações de interação social. Esse comentário, entretanto, não significa que os interiores domésticos setecentistas não se prestassem a abrigar reuniões sociais, haja vista que foram localizados mais de 350 móveis de assento, entre tamboretes e cadeiras.

Inácia Maria Rodrigues, por exemplo, esposa do mercador Lopo dos Santos Serra, falecida em 1768, dispunha de 51 móveis de assento - distribuídos entre 28 cadeiras, 13 tamboretes, dois mochos, uma poltrona e sete escabelos em sua residência no centro da capital. Neste inventário já reaparece a designação cadeiras ao lado de tamboretes, e o que percebemos pelas descrições é que as primeiras se caracterizavam pelo encosto de jacarandá e pés de cabra: "uma dúzia de cadeiras de encosto de jacarandá de pés de cabra grandes com assento de sola lavrada";36 "dez cadeiras de encosto de jacarandá mais pequenas com assento de sola lavrada"; "seis ditas [cadeiras] de encosto de jacarandá e assentos de marroquim de pés de cabra".

Os atributos físicos levados em consideração pelos avaliadores no que tange aos pés e espaldares denotam tratar-se de novos tipos de móveis de assento que se estavam introduzindo no espaço doméstico, trazendo consigo práticas sociais que pressupunham mais pessoas acomodadas em cadeiras nas salas de recepção. ${ }^{37}$

A menção a pés de cabra possivelmente indica que as pernas dianteiras das cadeiras e tamboretes eram curvas e terminavam em volutas sobre sapatas (denominadas pés de cachimbo em Portugal) ${ }^{38}$ (imagem 1). Tais características afastam as peças das tradicionais cadeiras de sola mencionadas anteriormente, o que é reforçado pelas descrições do espaldar de jacarandá - provavelmente vazado - e do assento de couro ou marroquim.

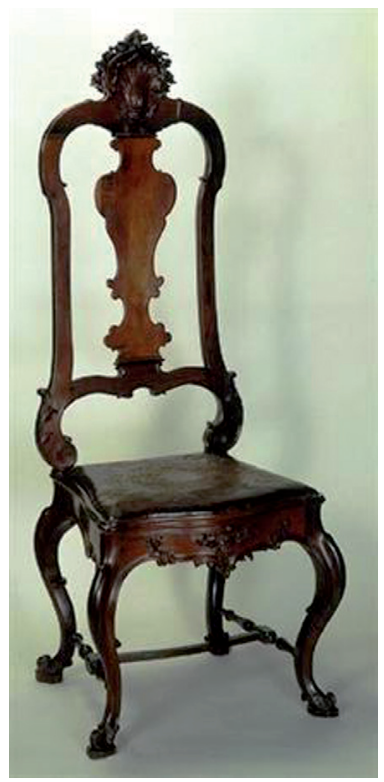

Imagem 1

Cadeira - Museu Nacional de Arte Antiga, Lisboa. http://www.matriznet.dgpc.pt/ MatrizNet/Objectos/ObjectosConsultar.aspx?IdReg=254193. Acesso em 9 nov. 16.

\footnotetext{
${ }^{36}$ Móvel de características semelhantes às descrições dos inventários pode ser encontrado no Museu Nacional de Arte Antiga, em Lisboa. Disponível em: http://www.matriznet.dgpc.pt/ MatrizNet/Objectos/ObjectosConsultar.aspx?IdReg=254193.

${ }^{37}$ Móveis semelhantes só foram identificados no inventário do abastado boticário Francisco Coelho Aires, aberto em 1776.

${ }^{38}$ Cf. CANTI, Tilde. O móvel no Brasil: origens, evolução e características. Rio de Janeiro: Ed. Cândido Guinle de Paula Machado, 1980, p. 249.
} 
Maria Aparecida de Menezes Borrego \& Rogério Ricciluca Matiello Félix

Ambientes domésticos e dinâmicas sociais em São Paulo colonial

Além disso, os valores alcançados pelas cadeiras foram superiores aos dos tamboretes com encosto. Para que se tenha uma ideia, as cadeiras com pés de cabra foram avaliadas em cerca de $\$ 500$ a unidade, enquanto os "oito tamboretes de madeira de encosto bem feitos" contabilizados na residência de Antônio Barbosa de Lima, em 1764, alcançaram a cifra de 3 \$200, ou seja, \$400 a peça.

Perceba-se que estamos tratando de um período em que, segundo a historiografia, a casa ainda não era considerada um espaço de distinção e, portanto, seria caracterizada pelo despojamento material. Contudo, os dados levam a crer que, na cidade de São Paulo, o segmento mercantil já começava a fazer do ambiente doméstico palco para a recepção de visitas em maior número, já que cada vez mais se enchiam os recintos com mobiliário de assento. Tanto o número das peças como a predominância dos comerciantes entre os seus maiores detentores indicam serem eles os principais difusores de práticas de convívio social nos interiores das residências paulistanas, adiantando para a segunda metade do século XVIII comportamentos disseminados na centúria seguinte, notadamente entre os membros da elite.

Nesse caso, parece ficar evidente que a casa não é somente um espaço eficaz para a reprodução de condutas sociais, mas também é neste ambiente que as transformações são engendradas, não como meros reflexos do mundo exterior, mas como parte ativa na indução dessas alterações. ${ }^{39}$

Interessante perceber, contudo, que nos inventários setecentistas paulistas não há menção a móveis coletivos como canapés, ainda que em Portugal eles já fossem confeccionados desde a segunda metade do século XVIII, com assento forrado de tecido ou de palhinha. ${ }^{40}$ Em São Paulo esses móveis estrearam nas salas de visitas somente nos inícios dos Oitocentos, reproduzindo a forma e a decoração das cadeiras que os ladeavam, quando o processo de interiorização das sociabilidades já estava mais vulgarizado, sobretudo entre os membros da elite. ${ }^{41}$

O que temos em termos de móveis coletivos são bancos e escabelos. Segundo Raphael Bluteau, cujo Vocabulario portuguez e latino data das décadas de 1710 e 1720, banco corresponde a um "assento comprido de madeira, no qual

\footnotetext{
${ }^{39}$ CARVALHO, Vânia Carneiro de, op. cit., 2008, p. 216.

${ }^{40}$ FREIRE, Fernanda Castro. Mobiliário, v. 1. Lisboa: Fundação Ricardo do Espírito Santo Silva, 1994; PINTO, Pedro da Costa. O móvel de assento português do século XVIII. Lisboa: Mediatexto, 2005.

${ }^{41}$ BORREGO, Maria Aparecida de Menezes. Laços familiares e aspectos materiais da dinâmica mercantil na cidade de São Paulo (séculos XVIII e XIX). Anais do Museu Paulista. História e cultura material, vol. 18, n. 1, São Paulo, 2010, p. 11-41.
} 
Maria Aparecida de Menezes Borrego \& Rogério Ricciluca Matiello Félix

Ambientes domésticos e dinâmicas sociais em Sc̃o Paulo colonial

muitos se podem assentar no mesmo tempo". ${ }^{42}$ Definição semelhante é a ele atribuída por Antônio de Moraes Silva, em 1789, quando escreve ser "assento grosseiro de táboa, estreita, com encosto, ou sem ele".43

De forma geral, as descrições de tais peças nos inventários consultados não nos permitem inferir o seu emprego; entretanto, quando são registrados como "de caixa com sua fechadura sem chave de 15 palmos de comprido e dois de largo", como ocorre no inventário do comerciante Alexandre Monteiro de Sampaio, aberto em 1755, conjectura-se que eram alocados junto às paredes e, outrossim, utilizados como móveis para conter e guardar. Nesse sentido, aproximam-se dos arquibancos, utilizados na Bahia colonial, descritos por Maria Helena Flexor como "banco-arca de encosto alto e assento móvel". ${ }^{4}$ Segundo Carlos Franco, a denominação arquibanco para móveis desse tipo provém do francês archebanc, "que são assim denominados porque, na realidade, são formados por arcas ou 'caixas' cujos bancos também servem como assento". 45

Esta última definição também cabe para o escabelo, que figura nos documentos paulistas. Diferentemente do móvel descrito por Bluteau como "assento pequeno de madeira, sem braços, nem espaldares", ${ }^{46}$ igualmente assim considerado por Flexor, os escabelos registrados nos inventários da amostra podiam chegar a medir 13 palmos, eram providos ou não de encosto e alguns possuíam tampa e fechadura no assento. Segundo Tilde Canti, tal móvel figurava nas cozinhas portuguesas ou nas igrejas. ${ }^{47}$ Para o contexto paulista, a única menção a sua alocação foi no alpendre do sítio do próprio Alexandre Monteiro de Sampaio, localizado na paragem do Ipiranga.

Tanto nas descrições dos bancos como dos escabelos, os avaliadores não se preocuparam em registrar a qualidade da madeira com que foram confeccionados, o que sugere terem sido elaborados na própria cidade de São Paulo, no interior das propriedades, por mão de obra escrava, ou enco-

\footnotetext{
${ }^{42}$ Cf. BLUTEAU, Raphael. Vocabulario portuguez \& latino: aulico, anatomico, architectonico..., vol. 2. Coimbra: Collegio das Artes da Companhia de Jesus, 1712-1728, p. 28.

${ }^{43}$ Cf. MORAES SILVA, Antônio de. Diccionario da língua portuguesa, vol. 1. Lisboa: Officina de Simão Thaddeo Ferreira, 1789, p. 257.

${ }^{44}$ Cf. FLEXOR, Maria Helena, op. cit., 2009, p. 147.

${ }^{45}$ FRANCO, Carlos. O mobiliário das elites de Lisboa na segunda metade do século XVIII. Lisboa: Livros Horizonte, 2007, p. 77.

${ }^{46}$ BLUTEAU, Rafael, op. cit., vol. 3, p. 200.

${ }^{47}$ CANTI, Tilde, op. cit., p. 111.
} 
Maria Aparecida de Menezes Borrego \& Rogério Ricciluca Matiello Félix

Ambientes domésticos e dinâmicas sociais em São Paulo colonial

mendados a oficiais mecânicos ligados à madeira - carpinteiros, carapinas, marceneiros, entalhadores.

Já não foi o caso das descrições de tamboretes e cadeiras. Os primeiros eram produzidos preferencialmente a partir do vinhático ou de madeira "da terra" - termo utilizado, a nosso ver, para designar móveis de uso corrente -, enquanto nas cadeiras já se empregava o nobre jacarandá, destinado à produção de peças de luxo ou honra. ${ }^{48}$

Mas não só. Vários outros móveis, como os bufetes, contaram com o registro das matérias-primas utilizadas, os modos de trabalhá-las, os ornamentos que lhe constituíam, jogando luzes sobre a produção de mobiliário colonial e os artífices envolvidos nessa atividade, temas ainda pouco trabalhados pela historiografia para o contexto paulista. ${ }^{49}$

\section{b. Comer, escrever, jogar e... exibir}

Dos móveis de apoio ou suporte, três se destacam nos interiores coloniais paulistas: bancas, mesas e bufetes. Pelos significados atribuídos por Bluteau às peças, acreditamos que bufete fosse, por assim dizer, a peça primária, de onde se originariam banca e mesa, uma vez que a sua definição é curta e direta - "em que se escreve ou em que se conta dinheiro".50 O padre não lançou mão dos termos móvel, objeto ou peça para caracterizar o artefato em que se realizava determinada ação, como se fosse de conhecimento geral, ao contrário das explicações para os demais móveis, que continham o termo "bufete" para esclarecer as suas funções. Assim, temos banca como "bofete onde os letrados escrevem"51 e mesa como "móvel da casa em que se põem os pratos para comer. Com esse mesmo nome se chamam os bofetes em que se escreve ou se joga, ou que servem de ornato para casa, porque de ordinário tem o mesmo feitio". ${ }^{52}$ Se tais definições nos informam sobre as fi-

\footnotetext{
${ }^{48}$ BRANDÃO, Angela. Anotações para uma história do mobiliário brasileiro do século XVIII. Revista CPC (USP), vol. 9, 2009-2010, p. 42-64.

${ }^{49}$ RABELLO, Elizabeth Darwiche. Os ofícios mecânicos e artesanais em São Paulo na segunda metade do século XVIII. Revista de História, n. 112, 1977, p. 575-588; FLEXOR, Maria Helena. Ofícios, manufaturas e comércio. In: SZMRECSÁNYI, Tamás (org). História econômica do período colonial. São Paulo: Hucitec, 2002; FERNANDES, Antônia Terra de Calazans. Memórias de ofício. Tese de doutorado em História Social, Faculdade de Filosofia, Letras e Ciências Humanas, Universidade de São Paulo, São Paulo, 1997.

${ }^{50}$ BLUTEAU, Raphael, op. cit., vol. 2, p. 141.

${ }^{51}$ Ibidem, vol. 2, p. 27.

${ }^{52}$ Ibidem, vol. 5, p. 446.
} 
Maria Aparecida de Menezes Borrego \& Rogério Ricciluca Matiello Félix

Ambientes domésticos e dinâmicas sociais em Sc̃o Paulo colonial

nalidades de cada móvel, elas não conseguem dar conta dos atributos físicos que as distinguem, nem dos usos sociais específicos dados pelos moradores da cidade de São Paulo no século XVIII.

Refiro-me, por exemplo, ao caso da banca que, no inventário do comerciante Gaspar de Matos, é descrita como "uma banca de jacarandá em que se come". Esse detalhe no registro dos avaliadores talvez indicasse justamente que o móvel estava sendo utilizado para um fim não previsto originalmente. Ainda que Bluteau o associasse à prática da escrita, nas décadas iniciais dos Oitocentos, cada vez mais banca esteve atrelada ao carteado, como atestam os inventários paulistas em que figuram bancas "para jogar cartas", "de abrir para jogos", "com embutidos para jogos", "de jacarandá de abrir forrada de baeta verde". O lazer associado aos jogos e a proliferação de móveis destinados a tal fim nos interiores domésticos foram também constatados por Nuno Madureira e Carlos Franco para o contexto lisboeta, ainda na segunda metade do século XVIII. ${ }^{53}$

De jacarandá ou vinhático, tal como as mesas, as bancas eram feitas na terra. Ambos os móveis se aproximam em termos de características materiais e dimensões, sendo retangulares ou redondos, com ou sem gavetas, sendo o elemento diferenciador entre eles o uso das mesas para práticas alimentares, embora esse fato raramente fosse apontado.

No decorrer do século XIX, o aprofundamento da interiorização das sociabilidades e a individuação dos aposentos das moradas das elites encontraram contrapartida na especialização dos móveis de suporte, que passaram a se multiplicar nos interiores domésticos para os mais diversos fins, seguindo a tendência do reino. ${ }^{54}$ Mesas para chá, mesas de canto, mesas de jantar, mesas de sofá, mesas de jogos de gamão, mesas de encostar são alguns exemplos da variedade de práticas sociais que se desenvolviam intramuros intermediadas pelos móveis de suporte.

Ainda que tais práticas não fossem comuns na capital paulista do século XVIII, o recheio da casa do mercador Lopo dos Santos Serra, revelado quando do inventário de sua esposa, mostra mais uma vez que nas casas dos agentes mercantis as relações sociais com pessoas estranhas ao núcleo familiar começaram a se intensificar. Ao lado das dezenas de móveis de assento já

\footnotetext{
${ }^{53}$ MADUREIRA, Nuno Luis. Cidade: espaço e quotidiano. Lisboa 1740-1830. Lisboa: Livros Horizonte, 1992; FRANCO, Carlos, op. cit., 2007.

${ }^{54}$ Para o caso português - e que inspira nossas análises - ver o trabalho seminal de Nuno Madureira. MADUREIRA, Nuno Luis, op. cit., 1992.
} 
Maria Aparecida de Menezes Borrego \& Rogério Ricciluca Matiello Félix

Ambientes domésticos e dinâmicas sociais em São Paulo colonial

arroladas, foram computadas oito mesas, sendo "uma de jacarandá, redonda com duas gavetas e pés torneados (...) uma mesa pequena, redonda, de um só pau no meio (...) seis mesas de madeira da terra com suas gavetas". Além disso, o número de mesas desse segmento social chega a quase triplicar em face daqueles disponíveis nos domicílios do restante da sociedade.

A presença dos bufetes marcaria ainda mais a diferenciação entre a população na cidade de São Paulo, uma vez que eram considerados móveis de aparato. De acordo com Carlos Franco, em Lisboa, esse móvel começou a ser abandonado na segunda metade dos Setecentos em razão da emergência de novas modas e valores. Em São Paulo, entretanto, os bufetes preponderaram até a década de 1770 entre os móveis de suporte e são expressivos da ostentação de riqueza e prestígio do grupo mercantil.

Tal como no caso dos detalhes dos pés de cabra e dos encostos de jacarandá nas cadeiras, foram os atributos físicos do artefato que revelaram a singularidade dos bufetes existentes nas casas dos comerciantes e seus familiares, servindo como dispositivos materiais de distinção social.

Comecemos pelo número de gavetas do móvel e a matéria-prima utilizada em sua estrutura. Se as gavetas eram comuns em bancas e mesas, em geral limitadas a duas unidades, como também era corrente em bufetes espalhados nos interiores domésticos paulistas, as peças descritas nos inventários dos abastados negociantes Gaspar de Matos, Manoel José da Cunha, André Álvares de Castro, Manoel Mendes de Almeida, Maria Francisca Lustosa - filha de João Francisco Lustosa -, José da Silva Ferrão, Manoel Soares de Carvalho e Francisco Pereira Mendes contavam com gavetas em número de quatro, o que indica serem móveis apropriados ao centro dos aposentos, lugar favorável a sua leitura total, já que decorados em todas as faces.

Ademais, esses móveis de quatro gavetas - ainda que duas fossem falsas - dispostos quase exclusivamente nas moradas dos agentes mercantis, ${ }^{55}$ eram confeccionados em jacarandá e alguns em madeira da Bahia, o que implica a importação de matéria-prima ou do próprio móvel da maior região produtora de mobiliário da colônia e, portanto, maior dispêndio para sua aquisição. As descrições de bufete no inventário de Gaspar de Matos, datado da década de 1730, embasam nossas análises acerca da procedência de determinadas peças e dos valores envolvidos. O rico comerciante era detentor de dez bufetes, sendo um deles “de jacarandá feito na Bahia com quatro gavetas

\footnotetext{
55 Somente em 1782, quando da morte do pintor Francisco Duarte do Rego, encontramos o registro de "dois bofetes de jacarandá da Bahia torneados com quatro gavetas cada um".
} 
Maria Aparecida de Menezes Borrego \& Rogério Ricciluca Matiello Félix

Ambientes domésticos e dinâmicas sociais em Sc̃o Paulo colonial

e suas fechaduras torneados os pés" e outro registrado como "feito na terra ao uso da Bahia com três gavetas e fechaduras já velho", avaliados respectivamente em 24\$000 e $8 \$ 000$.

Na década de 1780, os bufetes confeccionados na Bahia, ainda que velhos, alcançavam valores superiores aos seus congêneres produzidos em São Paulo. Para que se tenha uma ideia, "um bufete da Bahia grande, já velho com quatro gavetas, duas com chaves", foi avaliado em 12\$800 no inventário de Francisco Pereira Mendes, aberto em 1781, enquanto "três bufetes com gavetas e um grande sem gavetas" foram contabilizados em 1\$000 - os com gavetas - e os sem gavetas em $\$ 900$.

Como móveis de aparato e decoração, para além das funções a eles atribuídas por Bluteau, os bufetes se prestavam a suportar oratórios e contadores e, nesses casos, deviam ser colocados junto às paredes, aproximando-se da observação de Tilde Canti, para quem "a partir de meados do século XVIII, os bufetes, embora conservando essa designação até o século XIX, passam a apresentar outra estrutura, transformando-se em mesa de encostar ${ }^{\prime \prime}{ }^{56}$

Entretanto, alguma diferença visível e concreta ainda devia subsistir entre mesas e bufetes, para que um termo não fosse tomado por outro pelos louvados, ${ }^{57}$ nivelando seus proprietários. Afora o número de gavetas e da procedência da madeira usada para a confecção de bufetes, havia nesses últimos a exclusividade das travessas entre as pernas. Talvez esse atributo físico, não mencionado pelos dicionaristas, nem pelos avaliadores, fosse a propriedade indiciária que o caracterizava material e simbolicamente, de amplo conhecimento, o que dispensava sua alusão. ${ }^{58}$

Ao definir o bufete, Maria Helena Flexor assevera tratar-se de um "móvel mais alto e encorpado que a mesa, com pernas e travessas completamente torneadas, usado como aparador".59 Tal definição, elaborada com base em

\footnotetext{
${ }^{56}$ CANTI, Tilde, op. cit., p. 237.

${ }^{57}$ Em geral, os louvados eram escolhidos entre os oficiais mecânicos ligados à matéria-prima dos bens a serem avaliados. Tinha-se, portanto, carpinteiros avaliando móveis e ourives, joias. Entretanto, esse procedimento não era seguido à risca na cidade de São Paulo setecentista. No inventário do opulento homem de negócio Gaspar de Matos, aberto em 1735, o juiz de órfãos Carlos Clemente Cotrim, responsável pela condução do processo, afirmou que "visto não haver avaliador e partidor próprio no juízo nem o senado desta cidade ter destinado pessoa suficiente que fosse para este inventario", os avaliadores foram todos agentes mercantis.

${ }^{58} \mathrm{O}$ silenciamento quanto a características físicas constituintes primordiais dos móveis também foi flagrado para o formato abaulado dos tampos dos baús e para as abas dos tampos das canastras. Nesses três casos, foi fundamental a observação de peças remanescentes em acervos museológicos.

${ }^{59}$ FLEXOR, Maria Helena. O mobiliário..., op. cit., 2009, p. 148.
} 
Maria Aparecida de Menezes Borrego \& Rogério Ricciluca Matiello Félix

Ambientes domésticos e dinâmicas sociais em São Paulo colonial

milhares de inventários, contou com seu profundo conhecimento sobre os acervos museológicos da Bahia, que guardam remanescentes do mobiliário colonial. De fato, ao analisar os bufetes dos museus nacionais e portugueses ${ }^{60}$ constatamos a presença de travessas torneadas como componente diferenciador desses móveis em relação a outros de apoio ou suporte.

No Museu Paulista, dispomos de três exemplares de bufetes datados dos séculos XVII e XVIII, cujas características são a madeira de jacarandá, as gavetas, os pés torneados ligados por travessas ${ }^{61}$ (imagem 2). As peças variam de $81 \mathrm{~kg}$ a $110 \mathrm{~kg}$, chegando a ser de três a oito vezes mais pesadas que as mesas de chá, de canto, de apoio. Aos bufetes, portanto, permaneceram traços ligados à austeridade e à solidez, que muito bem podiam simbolizar o enraizamento do grupo mercantil na capital paulista.

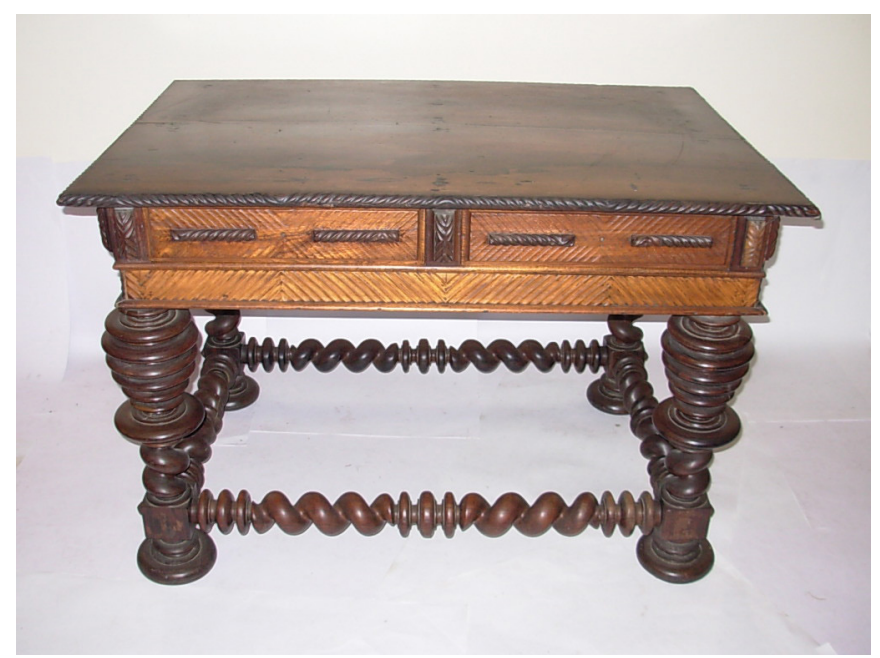

\section{Imagem 2}

Mesa: bufete - Museu Paulista - USP, São Paulo. Fotografia de Helio Nobre e José Rosael.

\section{c. Conforto e ostentação}

Por outro lado, a consolidação das fortunas e a sedimentação das populações em solo piratiningano também concorreram para a mudança de recheios das casas, com a entrada de peças especializadas, muitas vezes su-

\footnotetext{
${ }^{60}$ Consultar www.acervo.mp.usp.br; http://www.matriznet.dgpc.pt.

${ }^{61}$ Para visualizar a peça do museu, consultar o termo bufete em http://www.acervo.mp.usp.br/ MPAcervo/Objetos.aspx\#.
} 
Maria Aparecida de Menezes Borrego \& Rogério Ricciluca Matiello Félix

Ambientes domésticos e dinâmicas sociais em Sc̃o Paulo colonial

pérfluas, como era o caso dos preguiceiros, ${ }^{62}$ que atendiam ao conforto dos habitantes (imagem 3).

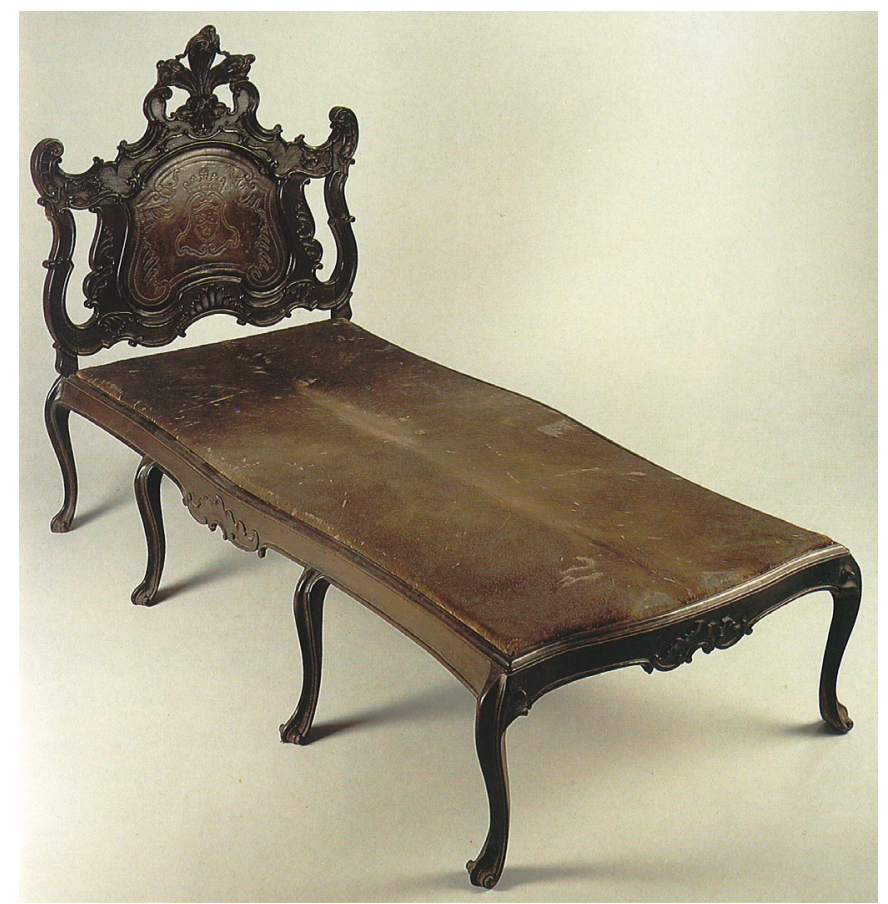

\section{Imagem 3}

Preguiceiro - Museu Histórico Nacional, Rio de Janeiro. Fotografia de Rômulo Fialdini. In MHN. São Paulo: Banco Safra, 1989, p. 165.

No que tange aos móveis de repouso, nos inventários compulsados, eles se restringiam a leitos, catres, camas de vento e aos já mencionados preguiceiros, o que não significa, entretanto, que fossem os únicos artefatos utilizados para dormir na América portuguesa, como atestam os relatos dos viajantes para inícios do século XIX. ${ }^{63}$ Ainda que não se referissem aos

\footnotetext{
${ }^{62}$ Como exemplos de preguiceiros, ver o móvel pertencente ao Museu Histórico Nacional, no Rio de Janeiro, cuja estrutura se assemelha às descrições constantes nos inventários paulistas, em SARMENTO, Therezinha de Moraes. Um preguiceiro no Museu Histórico Nacional. Anais do Museu Histórico Nacional, vol. XXI, 1969, p. 43-52, e o exemplar guardado na Casa Museu Dr. Anastácio Gonçalves, em Lisboa, em http://www.matriznet.dgpc.pt/MatrizNet/Objectos/ ObjectosConsultar.aspx?IdReg=243752.

${ }^{63} \mathrm{O}$ emprego de outros artefatos como suporte para o sono - tais como colchões - também fora constatado para o contexto lusitano tanto para os grupos intermédios como para as elites. Para o primeiro caso, Fernanda Olival comenta que "nem todas as pessoas teriam catre ou mobiliário de grande dimensão para repouso noturno. Pelos inventários orfanológicos e outras listas de bens nota-se que não havia uma relação direta entre o número de pessoas que habitavam numa casa e a quantidade destes móveis". Cf OLIVAL, Fernanda, op. cit., p.
} 
Maria Aparecida de Menezes Borrego \& Rogério Ricciluca Matiello Félix

Ambientes domésticos e dinâmicas sociais em São Paulo colonial

espaços domésticos paulistas, é possível que suas impressões pudessem ser estendidas a São Paulo.

John Luccock, por exemplo, comentou que o contrato de uma casa alugada por ele no Rio Grande do Sul, em 1809, o obrigava "a guardar uma enorme canastra reforçada com ferros, com duas fechaduras", que ele logo transportou para "fora da sala, convertendo-a em cama para o meu criado". ${ }^{64}$ Destinadas primordialmente para o armazenamento de gêneros para o transporte, as canastras também poderiam ser convertidas em barreira contra ameaças de ataques indígenas e/ou de animais e em apoio para o corpo cansado do tropeiro ou caixeiro durante as viagens no interior da América portuguesa, como as utilizadas nos Campos Gerais de Curitiba e retratadas por Jean Baptiste Debret, em Acampamento noturno de viajantes. ${ }^{65}$

Também são recorrentes para outros espaços coloniais relatos sobre o uso de redes, bancos, estrados e jiraus para dormir. ${ }^{66}$ As redes, aliás, foram utilizadas em toda a América do Sul, originalmente pelos povos nativos e depois por portugueses e seus descendentes. Seu uso social guarda, portanto, segundo Paulo Marins, "o apego às formas de sobrevivência e à cultura material dos indígenas no espaço da expansão paulista, indicando claramente uma americanização dos colonizadores e não apenas o inverso, isto é, a europeização das populações americanas". ${ }^{67}$

No caso das casas de morada dos comerciantes reinóis em São Paulo, tal apropriação é evidenciada pela existência simultânea de redes e de outros móveis de descanso. Ademais, as qualificações utilizadas pelos avaliado-

255. Já, para o segundo, Carlos Franco afirma que "o número de camas era manifestamente baixo tendo em conta o número de residentes". Cf. FRANCO, Carlos. O quarto de dormir e as artes decorativas em Lisboa. In: SOUSA, Gonçalo Vasconcelos e (org.) Matrizes para investigação das artes decorativas. Porto: Citar, 2010, p. 98.

${ }^{64}$ LUCCOCK, John. Notas sobre o Rio de Janeiro e partes meridionais do Brasil (1808-1818). São Paulo, Belo Horizonte: Edusp/ Itatiaia Editora, 1975, p. 126.

${ }^{65}$ DEBRET, Jean Baptiste. Voyage pittoresque et historique au Brésil. Paris: Firmin Didot Frères, 1835. Disponível em: http://www.brasiliana.usp.br/bbd/handle/1918/624520069. Segundo Jaelson Trindade, é duvidosa a presença de Debret no local do acampamento, que teria sido retratado pelo prussiano Friedrich Sellow, de quem o pintor francês teria copiado a imagem. TRINDADE, Jaelson Bitran. O fantasma de Debret. Revista de História. Rio de Janeiro: Biblioteca Nacional, 7 jan. 2008.

${ }^{66}$ Ao repousar numa choupana no Rio Grande do Sul, em 1821, Saint-Hilaire relatou que "como esta mísera habitação é ainda melhor que as dos índios, alguns milicianos, que aqui se acham, passam a noite conosco, dormindo em um jirau feito de bambus". SAINT-HILAIRE, Auguste de. Viagem ao Rio Grande do Sul (1820-1821). São Paulo, Belo Horizonte: Edusp/ Itatiaia Editora, 1974, p. 110.

${ }^{67}$ MARINS, Paulo Garcez. Vida cotidiana entre os paulistas: moradias, alimentação, indumentária. In: SETUBAL, Maria Alice (org.). Terra paulista: histórias, arte, costumes. São Paulo: C. Imesp, 2004, p. 92. 
Maria Aparecida de Menezes Borrego \& Rogério Ricciluca Matiello Félix

Ambientes domésticos e dinâmicas sociais em Sc̃o Paulo colonial

res como "com bastante uso", "ainda boa", "com bastantes buracos", "usadas", "com suas roturas" reforçam seu emprego intenso e cotidiano, mas não único para o repouso. Fossem usadas ou novas, as redes descritas eram de fio de algodão, provavelmente confeccionadas nos teares domésticos.

Tendo em conta a versatilidade de móveis para assento, guarda e descanso, a variedade de suportes para o sono e o grau de improviso, a própria existência de móveis de repouso nos inventários já é relevante, pois sinal de especialização do mobiliário e do aposento e dispêndio de capital em objetos para fins de maior conforto. Ter ao menos um catre de tábuas ou de cipó já significava não dormir no chão, ou em redes coletivas ao modo de alguns povos indígenas, ${ }^{68}$ ou ainda não fazer duplo uso dos estrados, caixas e bancos por todos os residentes do domicílio.

Detendo-nos especificamente nos leitos e catres, um primeiro problema que surge para o estudo social de seus usos refere-se à terminologia empregada pelos coevos. Mais uma vez, a imprecisão na maneira como os móveis eram descritos leva-nos a pensar se os avaliadores não usavam ambos os termos como sinônimos em algumas ocasiões. De acordo com os registros nos inventários, tanto os leitos quanto os catres podiam ser feitos na terra, de jacarandá, torneados, com balaústres; possuir tecidos de couro ou de tabuletas e cabeceira de talha.

Atentemos, então, para as diferenças entre as peças, a começar pelos valores. Embora os catres apresentassem grande variação de preços - de $\$ 160$ a $6 \$ 400$-, a maioria transitava na faixa de \$460 a \$800. Já os leitos atingiam valores bem mais elevados, haja vista que os mais baratos ainda eram indiscutivelmente mais dispendiosos do que os catres mais caros. A avaliação iniciava-se em $3 \$ 200$ para um leito de madeira da terra e podia chegar a $40 \$ 000$ para um de jacarandá baiano.

Tais diferenças podem ser explicadas novamente pela materialidade das peças. Segundo Bluteau, catre era um "leito pequeno, com pilares, não totalmente levantados". ${ }^{69}$ Para a realidade baiana, Maria Helena Flexor afirma

\footnotetext{
${ }^{68}$ Apesar de ser recorrente a historiografia tratar os hábitos dos povos indígenas de maneira planificada, muito devido à indisponibilidade de fontes, no caso das formas de repouso, o registro de Spix e Martius permite-nos particularizá-los. Referindo-se em 1818 aos índios Camacans, em Ferradas, Bahia, escrevem: “Não se deitam em redes, porém num jirau de grades de madeira, que eles cobrem com folhas secas e peles de animais". SPIX, Johann Baptiste von \& MARTIUS, Carl Friedrich Philippe von. Viagem pelo Brasil (1818-1819), vol. II. Rio de Janeiro: Imprensa Nacional, 1938, p. 344.

${ }^{69}$ BLUTEAU, Raphael, op. cit., vol. 2, p. 203.
} 
Maria Aparecida de Menezes Borrego \& Rogério Ricciluca Matiello Félix

Ambientes domésticos e dinâmicas sociais em São Paulo colonial

que o termo catre serviu para designar camas pobres, sendo substituído em meados dos Setecentos pela palavra cama.

Para São Paulo, com base nos inventários de nossa amostra, os valores apresentados para os catres poderiam subsidiar a afirmação da autora, mas não totalmente, pois localizamos alguns mais elaborados, como o de Gaspar de Matos, descrito em 1734, como "feito na terra, grande com seus balaústres, torneado em bom uso", ou o de Manoel Mendes de Almeida, registrado em 1756, como "torneado, feito nesta terra, com a cabeceira meia talha e dourada", ou ainda o que figura no processo do mercador Manuel de Faria Couto, aberto em 1780, "com cabeceira de balaústres torneados, tecido de couro".

Por outro lado, há descrições nos inventários que revelam que alguns catres eram confeccionados com uma matriz longe de ser requintada: o cipó. O primeiro fator a ser notado é que tecidos de cipó somente existiam neste tipo de móvel de repouso e figuraram em poucos casos. ${ }^{70}$ Em realidade, o ripado de couro era a matéria-prima do estrado para catres e predominava nos inventários dos comerciantes. ${ }^{71}$

Os catres tecidos de couro eram mais práticos no meio tropical, dispensando o uso de colchões de algodão - ou outros enchimentos - para o repouso sobre as rígidas tábuas, chamadas "de tabuletas". Além de fáceis de desmontar e transportar, os catres com tecidos de couro eram arejados e deviam ser mais higiênicos, em face da possibilidade de fácil infestação dos colchões de pano e algodão por insetos que empesteavam os interiores domésticos.

Por fim, não localizamos o termo cama em lugar de catre naquele período, apenas mencionado ao se referir às camas de vento ${ }^{72}$ ou às camas de rede, muito mais atreladas ao transporte e inconstância do que à fixação e sedimentação. Poderia aí residir outra especificidade do espaço doméstico paulista frente ao soteropolitano, dentre tantas similaridades.

\footnotetext{
${ }^{70}$ Entre os comerciantes, somente Manuel Luís da Costa, falecido em 1755, era proprietário de "um catre da terra tecido de cipó", mas ele era um vendeiro, não se comparando aos mercadores que, com o tempo, foram se tornando abastados homens de negócios.

${ }^{71}$ Este fato chama a atenção para a importância de se estudar a criação de gado na região de São Paulo e o transporte e comércio dos rebanhos e seus derivados entre as várias regiões do Brasil.

${ }^{72}$ Camas de ventos eram assim chamadas devido aos colchões de couro cheios a ar. Eram exclusivas da amostra dos comerciantes e seus valores oscilavam entre $1 \$ 920$ a $3 \$ 840$, sendo, portanto, altos em comparação aos dos catres, mas intermediários na faixa geral. Tais preços nos levam a inquirir se valor mais alto das camas de vento não se daria pela sua especificidade funcional e pela tecnologia empregada em sua materialidade, que as transformavam em artefato dobrável e retrátil para o transporte.
} 
Quanto aos leitos, os valores a eles atribuídos estavam relacionados não só aos trabalhos de torno e de entalhe empregados, mas também - e, sobretudo - a suas procedências - Bahia, Rio de Janeiro e, até mesmo, França, como o "leito francês de vinhático quase novo", mencionado no inventário do mercador João Rodrigues Vaz, aberto em 1746. Esse padrão diferenciador dos objetos pela sua proveniência era um elemento fortemente marcado nos inventários dos comerciantes, que eram os maiores possuidores de móveis de repouso com madeira de jacarandá da Bahia, padrão que se repete, como já visto, para outras tipologias de mobiliário.

Novamente, o recheio da casa atesta o contato da cidade de São Paulo com várias regiões coloniais e o comércio mútuo com enriquecimento recíproco. Como zona de permanência e consolidação de fortunas, a capital paulista contou com a presença de móveis importados de caráter perene, com madeira de lei e com rico trabalho de talha encomendados pelos reinóis aí residentes e, ao que tudo indica, disseminados por eles.

Para além do fato de os mais caros e ornamentados móveis serem importados, os leitos eram os únicos que contavam com armação e dosséis, elementos diferenciadores não só entre os móveis de repouso, mas entre os proprietários, se considerarmos as suas implicações materiais (imagem 4).

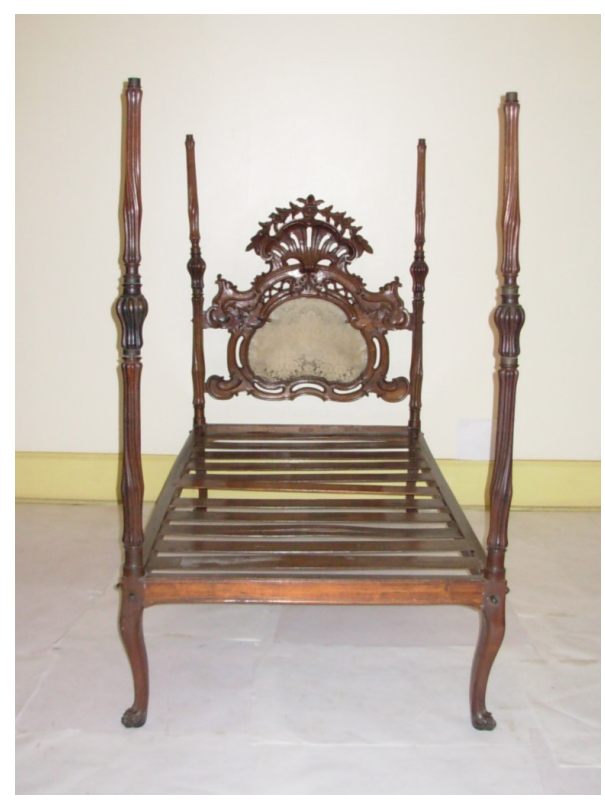

\section{Imagem 4}

Leito: cama - Museu Paulista - USP, São Paulo. Fotografia de Helio Nobre e José Rosael.

Em primeiro lugar, os cortinados serviam como obstáculo para evitar os indesejados insetos que perturbavam o cotidiano dos indivíduos, especialmente no momento do sono. São sintomáticas as descrições da ubiqui- 
Maria Aparecida de Menezes Borrego \& Rogério Ricciluca Matiello Félix

Ambientes domésticos e dinâmicas sociais em São Paulo colonial

dade dos insetos atrapalhando o dia-a-dia dos habitantes de terras tropicais, como as 450 pulgas que o padre Jerônimo Rodriguez chegou a matar em sua cama $^{73}$ ou os barbeiros que na noite se aventuravam para fora das frestas das casas de paredes de barro. ${ }^{74}$

Barrando insetos e filtrando a luminosidade, os cortinados também cumpriam a função de preservar o pouco resguardo de seus usuários. Em casas cujos cômodos geralmente serviam a mais de uma função e cujas divisões internas eram poucas, o recurso ao dossel se fazia premente, sobretudo nas alcovas que, como nos lembra Leila Mezan Algranti, ficavam nos centros das casas e eram espaço de passagem. ${ }^{75}$

Os quartos propriamente ditos foram verdadeiras inovações que se disseminaram ao longo do século $\mathrm{XIX}^{76}$ sendo tomados como luxo de casas abastadas ou ocorrências pontuais de construções mais humildes. ${ }^{77}$ Nas alcovas espalhadas pelos interiores coloniais, dormiam não só o casal, mas também os filhos, os agregados mais próximos e porventura os escravos, aos quais geralmente eram reservados o chão das cozinhas e/ou os jiraus dos falsos sobrados.

Se o ambiente doméstico densamente habitado ajuda a explicar a importância dos panos dos dosséis para a intimidade do casal no leito, servindo de barreira aos olhares indesejados em casas cheias de frestas e portas sem fechaduras, por outro lado, há que se levar em conta que tanto em Portugal quanto na colônia o sexo não ocorria apenas na cama, como denunciam as fontes de época, trabalhadas por Fernanda Olival, Ronaldo Vainfas e Mary del Priore. ${ }^{78}$

Por fim, possuir um leito com armação e dossel de damasco - ou de damasquilho - significava um consumo conspícuo por parte dos comerciantes, bem diferente do de seus contemporâneos paulistas ${ }^{79}$ que, embora

\footnotetext{
75 SOUZA, Laura de Mello e. O diabo e a Terra de Santa Cruz: feitiçaria e religiosidade popular no Brasil colonial. São Paulo: Companhia das Letras, 1986, p. 47.

${ }^{74}$ MARTINEZ, Cláudia Eliane Parreiras Marques. A natureza dentro da casa paulista. In: MARTINEZ, Paulo Henrique (org.). História ambiental paulista: temas, fontes e métodos, vol. 1. São Paulo: Senac, 2007, p. 51-69.

${ }^{75}$ ALGRANTI, Leila Mezan, op. cit., 1997, p. 101.

${ }^{76}$ Ver MARINS, Paulo Cesar Garcez, op. cit., 2004.

${ }_{77}$ No caso de Vila Rica. ALGRANTI, Leila Mezan, op. cit., 1997, p. 102.

${ }^{78}$ OLIVAL, Fernanda, op. cit., 2011, p. 256; VAINFAS, Ronaldo. Moralidades brasílicas: deleites sexuais e linguagem erótica na sociedade escravista. In: SOUZA, Laura de Mello e (org.). História da vida privada no Brasil, vol. 1. São Paulo: Companhia das Letras, 1997, p. 221-273; DEL PRIORE, Mary. Histórias íntimas: sexualidade e erotismo na história do Brasil. São Paulo: Planeta, 2011, p. 24.

${ }^{79}$ Enquanto encontramos mais de duas dezenas de leitos entre a amostra do grupo mercantil ao longo de todo o período, apenas três foram localizados entre os bens dos senhores de terra José Barbosa de Lima e Antônio Barbosa de Lima.
} 
Maria Aparecida de Menezes Borrego \& Rogério Ricciluca Matiello Félix

Ambientes domésticos e dinâmicas sociais em Sc̃o Paulo colonial

contassem com cortinados em móveis de repouso, eles eram fabricados em pano de algodão, bem mais econômicos. Para que se tenha uma ideia, "um cortinado de pano de algodão quarteado em bom uso" do senhor de terras José Barbosa de Lima fora avaliado, em 1755, em $8 \$ 000$, ao passo que, na mesma década, ao "cortinado de cama ${ }^{80}$ do dito damasco" do comerciante André Alvares de Castro fora atribuído o valor de $28 \$ 800$ e ao "cortinado de damasco singelo amarelo com franjas" do homem de negócio Manoel Mendes de Almeida, 48\$000.

Infelizmente não dispomos de tantos remanescentes de leitos e muito menos de dosséis, em acervos museológicos brasileiros, pois, como bem salientou Flexor, era costume deitar fora ou queimar o móvel onde o doente falecera. Entretanto, se a morte poderia levar à destruição do leito/ catre, era a cura da doença, por meio de uma graça alcançada, que viria a perpetuar iconograficamente os móveis de repouso por meio das tábuas votivas.

Nos quadrinhos de ex-votos, geralmente a cena representava o que era descrito na legenda, havendo uma intenção de reproduzir o fato que originou a promessa. No caso das tábuas votivas referentes a enfermidades, pode-se constatar a existência de um esquema de confecção das imagens cujo núcleo básico era composto pela representação do enfermo numa cama e, numa das extremidades da pintura, o santo envolto em nuvens. ${ }^{81}$

Embora tais peças coloniais ainda não tenham sido objeto de estudo para o contexto paulista, as tábuas o foram para a região das Minas Gerais, sobretudo de Congonhas do Campo, onde muitas ficaram guardadas na sala dos milagres do Santuário do Bom Jesus do Matosinhos. Estudados por Robert Smith ${ }^{82}$ para a análise dos interiores domésticos, os ex-votos pintados em madeira foram objeto de investigação de Julita Scarano, Marcia de Moura Castro, Jean Neves de Abreu e Beatriz Helena Ramsthaler Figueiredo. ${ }^{83}$

\footnotetext{
${ }^{80}$ Segundo Fernanda de Castro Freire, "durante séculos 'cama' significava apenas os têxteis (colchoaria, lençóis, dosséis, sanefas, cortinas, colchas) que, quando luxuosos, tinham maior valor que a estrutura de madeira". Cf. FREIRE, Fernanda de Castro, op. cit., p. 137. Entendemos que no caso dos inventários paulistas mencionados, o termo cama foi usado nessa acepção, e aqui também, por vezes, os têxteis alcançaram valor superior ao leito.

${ }^{81}$ ABREU, Jean Luiz Neves. Difusão, produção e consumo das imagens visuais: o caso dos exvotos mineiros do século XVIII. Revista Brasileira de História, vol. 25, n. 49, São Paulo, 2005, p. 200.

${ }^{82}$ SMITH, Robert C. Pinturas de ex-votos existentes em Matosinhos e outros santuários portugueses. Matosinhos: Câmara Municipal de Matosinhos, 1966.

83 SCARANO, Julita. Fé e milagre: Ex-votos pintados em madeiras - século XVIII e XIX. São Paulo: Edusp, 2004. CASTRO, Marcia de Moura. Ex-votos mineiros: as Tábuas votivas no ciclo do ouro. Belo Horizonte: Expressão e Cultura, 1994; ABREU, Jean Luiz Neves de. O imaginário do milagre e a religiosidade
} 
Maria Aparecida de Menezes Borrego \& Rogério Ricciluca Matiello Félix

Ambientes domésticos e dinâmicas sociais em São Paulo colonial

Nas imagens mineiras, são comuns os cortinados vermelhos encobrindo o leito do doente. Para a realidade paulista, predominaram os panos de dossel de damasco/ damasquilho vermelho e amarelo. Segundo Figueiredo, as cores azul e vermelho eram recorrentes nos ambientes internos das igrejas coloniais e também estavam associadas à nobreza e ao poder, tanto que reis e rainhas eram retratados com o predomínio dessas tonalidades. ${ }^{84}$

Nesse sentido, de acordo com a autora, o uso do tom encarnado nos dosséis talvez indicasse tratar-se de uma pessoa de posses, o que para a nossa amostra tem o maior sentido. Provenientes do norte de Portugal, os comerciantes atravessaram o Atlântico em tenra idade e amealharam fortunas na lide mercantil, tornando-se os mais abastados de São Paulo em seu tempo. José Rodrigues Pereira, por exemplo, era o habitante mais rico da cidade, segundo os dados do censo de 1765, e Manoel Mendes de Almeida figurou no Registro Geral da Câmara Municipal de São Paulo, em 5 de julho de 1742, como "uma das principais pessoas da dita cidade e mais rico e opulento". ${ }^{85}$

A presença de tão caros e ornamentados móveis e têxteis nos inventários colocam-nos uma série de questões a respeito de seu uso do ponto de vista das sociabilidades e da ostentação. Sendo as moradas setecentistas pouco divididas internamente e com sobreposições de funções em cada cômodo, tentamos entender o dispêndio de notórias somas de dinheiro com móveis como os de repouso, em tese, não posicionados nas salas de recepção, as quais abrigavam outros móveis que, por vezes, desempenhavam a função de aparato como cadeiras, bufetes e preguiceiros.

Embora os inventários não nos tragam informações sobre a localização das peças nos recintos e a quem era dada a oportunidade e prerrogativa de apreciá-los, podemos aventar que tais móveis de repouso, mais ou menos suntuosos, de materiais nobres ou não, se prestavam, por um lado, para reforçar a própria hierarquia intramuros e, por outro, para reiterar nos domínios coloniais as marcas distintivas do reino.

\footnotetext{
popular: um estudo sobre a prática votiva nas Minas do século XVIII. Dissertação de mestrado em História, Faculdade de Filosofia e Ciências Humanas, Universidade Federal de Minas Gerais, Belo Horizonte, 2001. FIGUEIREDO, Beatriz Helena Ramsthaler. Os ex-votos do período colonial: uma forma de comunicação entre pessoas e santos (1720-1780). Dissertação de mestrado em História, Pontifícia Universidade Católica, São Paulo, 2010.

${ }^{84}$ FIGUEIREDO, Beatriz Helena Ramsthaler, op. cit., p. 104 e 120.

${ }^{85}$ Registo Geral da Camara Municipal de S. Paulo 1735-1742, vol. V. São Paulo: Typographia Piratininga, 1918, p. 462-465.
} 
Maria Aparecida de Menezes Borrego \& Rogério Ricciluca Matiello Félix

Ambientes domésticos e dinâmicas sociais em Sc̃o Paulo colonial

Analisando o mobiliário das elites lisboetas da segunda metade do século XVIII, Carlos Franco bem observa que "apesar da superior qualidade da madeira que era escolhida e de todo um generoso trabalho que envolvia os saberes do marceneiro, entalhador e torneiro, cabia aos tecidos que envolviam o leito prestar o devido tributo à ostentação e ao bem-estar". ${ }^{16}$ Ao que tudo indica, guardadas as devidas proporções, também na São Paulo colonial, conspicuidade e conforto ganhavam cada vez mais espaço entre os gastos dos enriquecidos comerciantes nos interiores domésticos, atualizando nas novas e - cada vez mais - definitivas casas de morada padrões vigentes na metrópole, de onde haviam partido ainda jovens em condições de vida bastante diversas.

Tal proposta analítica é corroborada pela existência de cinco preguiceiros exclusivamente pertencentes a dois comerciantes, cujos valores podiam atingir a cifra de $20 \$ 000$, correspondente ao mais caro dos quatro, possuídos por Inácia Maria Rodrigues, e descrito como "de jacarandá, coberto de sola picada, de pés de cabra e de armação", comportando, portanto, até cortinados.

Os preguiceiros ou espreguiceiros eram móveis cuja nomenclatura já é reveladora de seu caráter luxuoso. Como define Paixão "destinados ao repouso diurno, ou sesta (leitos de dia), permitem uma situação de maior conforto e relaxamento para o corpo, como por exemplo, pela elevação das pernas e reclinamento do dorso". ${ }^{87}$ Para além de confortáveis, eram confeccionados para serem vistos, pois colocados nas salas nobres das casas, complementando os móveis de assento. ${ }^{88}$

No caso dos móveis de repouso, os atributos materiais caracterizados simultaneamente pela robustez e conforto indicam, portanto, que a perenidade era um indício fulcral dos novos modos de morar que tais agentes implementaram na terra paulista em meados e na segunda metade do século XVIII.

\footnotetext{
${ }^{86}$ FRANCO, Carlos, op. cit., 2010, p. 95.

${ }^{87}$ PAIXÃO, Giselle Marques Leite, op. cit., p. 130.

${ }^{88}$ FLEXOR, Maria Helena, op. cit., 2009. No século XIX, os preguiceiros foram gradativamente sendo substituídos pelas marquesas. Justamente em razão do papel de destaque como palco de relações sociais, as salas de visitas e seu recheio ganharam nesse período a atenção dos investimentos do grupo mercantil, em detrimento do quarto de dormir e dos leitos, cada vez mais relegados à privacidade.
} 


\section{Produção e circulação do mobiliário colonial - algumas indagações}

Fosse para os assentos e espaldares de tamboretes e cadeiras ou para as cabeceiras e estrados de catres, leitos, camas de vento ou preguiceiros, encontramos larga utilização do couro e, em menor escala, do tecido ou cipó, fixado à estrutura do móvel com pregaria grande, miúda, grossa ou dourada.

O couro também era material que se prestava à promoção de distinção social, sendo suporte privilegiado para brasões, como marca de posse e elemento decorativo, ${ }^{89}$ principalmente quando empregado nos encostos dos tamboretes. A menção a couro/ sola lavrado(a) parece justamente indicar a aplicação de técnicas ornamentais às peças que hierarquizavam ainda mais os móveis e seus proprietários.

No Museu Paulista, temos um exemplar de uma cadeira de sola que pertencera ao rico proprietário de terras Antônio de Barros Penteado, ${ }^{90}$ residente na vila de Itu. É uma cadeira de jacarandá do século XVII, em linhas retas, de construção rústica, assento e espaldar guarnecidos de sola lavrada com cercadura e ramagens; no centro do espaldar, cartela com flores com o monograma "AP". Nos ângulos, remate de madeira em ectaedro. Pregaria de pequenas cabeças de latão. Pernas retas, angulares, com travessas simples ${ }^{91}$ (imagem 5).

\section{Imagem 5}

Cadeira: cadeira de sola - Museu Paulista - USP, São Paulo. Fotografia de José Rosael.

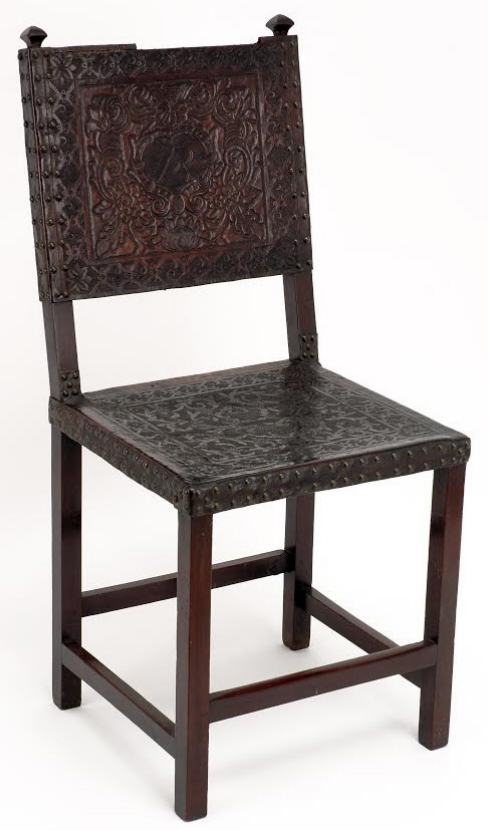

${ }^{89}$ FREIRE, Fernanda de Castro, op. cit., p. 19. Segundo Fernanda de Castro Freire, no couro lavrado, os sulcos são abertos na pele com pequenas lâminas a que se chamam vulgarmente de facas de incisão que são utilizadas como lápis, abrindo finas linhas nos couros que podem ser alargadas com o uso de estilete.

${ }^{90}$ Antônio Penteado era pai de Genebra de Barros Leite e foi sogro de seu primeiro marido, o brigadeiro Luis Antônio de Souza Queiroz, uma das maiores fortunas mercantis e agrárias da cidade de São Paulo nas décadas iniciais do século XIX. O móvel ingressou no Museu Paulista em 1923, por vontade testamentária de sua bisneta d. Francisca Miquelina de Souza Queiroz.

${ }^{91}$ RODRIGUES, José Wasth. Descrições de mobiliário. São Paulo: Museu Paulista, 1948. Datilografado e rubricado. 
Maria Aparecida de Menezes Borrego \& Rogério Ricciluca Matiello Félix

Ambientes domésticos e dinâmicas sociais em Sc̃o Paulo colonial

Analisando o contexto português, Fernanda de Castro Freire atribui a designação couro picado à peça cuja decoração é menos elaborada, feita com ferros próprios mais rústicos. Já para o caso brasileiro, José Wasth Rodrigues afirma que o termo sola picada era usado de forma abrangente, designando couro lavrado em geral. De toda a forma, como bem apontou Maria Helena Flexor, caindo o couro lavrado ou a sola picada em desuso, a palhinha foi o material preferido para os assentos das cadeiras, ${ }^{92}$ o que só viria a ocorrer de forma mais contínua na cidade de São Paulo a partir dos Oitocentos. Para o século XVIII, apenas localizamos uma peça com esse material - um mocho torneado coberto de palhinha - no sítio onde viveu o rico proprietário de terras José Barbosa de Lima, falecido em 1755.

As peças de mobiliário com couro lavrado levam-nos a conjeturar sobre a criação de gado para produção de mobiliário, sobre o fornecimento do couro por fazendas de gado mais próximas ou distantes da cidade - sobretudo do Rio Grande -, sobre o papel dos correeiros - artesãos que colocavam e fixavam os couros nos assentos - na confecção não só de móveis de assento, mas também de leitos, catres, preguiceiros, em conjunto com outros oficiais ligados à madeira.

Nos termos de fiança da documentação camarária setecentista - até 1765 -, foi constante a passagem de gado pela capital paulista, sobretudo em direção às Minas Gerais, ao Rio de Janeiro e a Goiás, secundadas por outras áreas da própria capitania, que poderiam consumi-las ou servir como entrepostos, dada a sua localização estratégica - Guaratinguetá, Santos, Piedade, Parnaíba, Mogi Guaçu. ${ }^{93}$

Com a abertura do caminho do Viamão, na década de 1730, as tropas de muares, vindas do Prata, de Curitiba e dos próprios campos de Viamão, passaram a se dirigir em maior quantidade e frequência para a feira de animais de Sorocaba. De lá, o gado comprado pelos negociantes era levado para diversas regiões, tendo a cidade de São Paulo como destino ou área de apoio. ${ }^{94}$

\footnotetext{
${ }_{92}$ FLEXOR, Maria Helena, op. cit., 2009, p. 110.

${ }^{95}$ Nesse lapso temporal, houve a taxação sobre as cabeças de gado para contribuição ao donativo voluntário para reconstrução de Lisboa, em virtude do terremoto ocorrido em 1755 . O fato de a pecuária figurar no topo da lista das mercadorias tributadas revela sua importância no conjunto de artigos comercializados na cidade de São Paulo. BORREGO, Maria Aparecida de Menezes. A teia mercantil..., op. cit., 2010.

${ }^{94}$ REIS Filho, Nestor Goulart. O caminho do Anhanguera. São Paulo: Via das Artes, 2014, p. 30-1.
} 
Maria Aparecida de Menezes Borrego \& Rogério Ricciluca Matiello Félix

Ambientes domésticos e dinâmicas sociais em São Paulo colonial

A implantação do registro de Sorocaba, ainda em 1750, comprova que o volume de cabeças trazidas para essa vila era atraente do ponto de vista fiscal. ${ }^{95}$

Acerca do intenso comércio entre a região sul e sudeste da América portuguesa no século XVIII, Renato Leite Marcondes comenta que, paralelamente à condução de tropas via terrestre para atender à demanda por transporte, vestuário e alimentação, realizava-se o envio de couro, sebo, carne seca e charque por via marítima. ${ }^{96}$ Entretanto, os estudos dos especialistas não são conclusivos sobre a extração do couro para utilização em mobiliário, nem no próprio Rio Grande do Sul, ou em São Paulo, nem sobre o trajeto de cabotagem percorrido pelo material. ${ }^{97}$

Já os móveis com assento de marroquim, as cabeceiras de leitos de tecido e os cortinados de dosséis de damasco nos levam a pensar na importação de tecidos para a América portuguesa que, no caso paulistano, poderiam ser comercializados nas lojas de fazenda seca, uma vez que foram encontrados nos estoques desses estabelecimentos, vendidos em vara ou côvado, baeta, pano, panico, seda, sarja, estamenha, droguete, cetim, veludo, damasco, camelão, barregana, brim, serafina, linha, olanda crua, chita, chita da Índia, fustão, tafetá, cambraia, linho, linha, bretanha, lã de camelo, lã inglesa, linhagem de Hamburgo, linhagem de olanda, renda, pelica, camurça, duquesa, ruão, riscado de Malta, riscado de Hamburgo, chamalote, olandilha, estopa, algodão, algodão da terra, melânia. Os produtos de couro eram de marroquim, bezerro, cordovão, carneira, baldréu e veado. ${ }^{98}$

Com relação ao damasco, contudo, localizamos peças à disposição de eventuais compradores somente na loja de Gaspar de Matos, descritas como

\footnotetext{
${ }_{95}$ Segundo Carlos Bacellar, "infelizmente, não sobreviveram quaisquer documentos contábeis desse Registro relativos ao século XVIII. Funcionando, desde o momento de sua criação até 1825, sob o sistema de arrendamento para particulares, os eventuais livros de controle de passagem de animais também ficaram sob a posse desses indivíduos". BACELLAR, Carlos de Almeida Prado. Viver e sobreviver em uma vila colonial - Sorocaba, séculos XVIII e XIX. São Paulo: Annablume/Fapesp, 2001, p. 101.

${ }^{96}$ MARCONDES, Renato Leite. Formação da rede regional de abastecimento do Rio de Janeiro: a presença dos negociantes de gado (1801-1811). Topoi, Rio de Janeiro, mar. 2001, p. 41-71.

${ }^{97}$ Sobre a criação de gado no sul da América portuguesa, ver OSORIO, Helen. O Império português no Sul da América: estancieiros, lavradores e comerciantes. Porto Alegre: Editora da UFRGS, 2007; HAMEISTER, Martha Daisson. O continente do Rio Grande de São Pedro: os homens, suas redes de relações e suas mercadorias semoventes (c. 1727-c. 1763). Dissertação de mestrado em História, Universidade Federal do Rio de Janeiro, Rio de Janeiro, 2002.

${ }^{98}$ BORREGO, Maria Aparecida de Menezes. A teia mercantil..., op. cit., 2010.
} 
Maria Aparecida de Menezes Borrego \& Rogério Ricciluca Matiello Félix

Ambientes domésticos e dinâmicas sociais em Sc̃o Paulo colonial

"cento e seis côvados e meio de damasco da Índia em duas peças e retalhos avaliados em 136\$320".

Se os agentes mercantis não eram responsáveis pela venda de mobiliário, pois se prestavam mais a fazer circular móveis de conter usados nas lojas de fazenda seca - "sete baús de carga de moscóvia com suas fechaduras e um sem chave", ou de "um baú usado com duas fechaduras", ou ainda de "duas caixas de madeira (...) uma das quais é quebrada"99 - poderiam ser responsáveis pela encomenda e compra de tecidos em Portugal, utilizados como matéria-prima para os carpinteiros, marceneiros ou entalhadores.

Durante esse período encontramos poucos marceneiros atuantes em São Paulo, ao contrário de carpinteiros, que aparecem em maior número na documentação camarária e nos maços de população. ${ }^{100}$

Para o caso mineiro, Jeaneth Araújo e Angela Brandão encontram sobreposição de atividades entre os distintos ofícios e a capacidade de certos artesãos de transitarem entre grandes obras de construção em madeira e peças de pequeno formato. ${ }^{101}$ Igualmente no Rio de Janeiro de meados dos Setecentos, a rígida divisão das funções exercidas por diferentes oficiais não se mantinha criteriosamente, pelo menos não entre entalhadores e marceneiros, como bem demonstrou Noronha Santos, analisando os autos de execução de 1759 a 1761 entre juízes dos ofícios de carpinteiros e marceneiros e o réu entalhador Francisco Félix da Cruz. ${ }^{102}$

Mas não só. A narrativa de Monica Martins acerca da tentativa de impedimento da admissão de mulatos na Irmandade de São José no Rio de Ja-

${ }^{99}$ BORREgO, Maria Aparecida de Menezes. Laços familiares..., op. cit., 2010.

${ }^{100}$ Assim estavam distribuídos marceneiros e carpinteiros nos censos de 1765 a 1798 :

\begin{tabular}{|l|c|c|c|c|}
\hline & 1765 & 1767 & 1776 & 1798 \\
\hline Marceneiros & 1 & 2 & 1 & 3 \\
\hline Carpinteiros & 12 & 8 & 12 & 8 \\
\hline
\end{tabular}

Cf. POLLETI, Daniel Nogueira. Relatório de Iniciação - Fapesp, 2011.

${ }^{101}$ ARAÚJO, Jeaneth Xavier de. Os artífices do sagrado e a arte religiosa nas minas setecentistas: trabalho e vida cotidiana. São Paulo: Annablume, 2013; BRANDÃO, Angela. Das pontes aos castiçais: a produção de mobiliário artístico em Minas Gerais do século XVIII e os ofícios mecânicos. Revista Científica, vol. 4. Curitiba: FAP, 2009, p. 50-66.

${ }^{102}$ SANTOS, Noronha. Um litígio entre marceneiros e entalhadores no Rio de Janeiro. Revista do Sphan, $\mathrm{n}^{\circ}$ 06, 1942, p. 295-317. A Irmandade de São José, ligada aos ofícios de carpinteiros e marceneiros, pretendia impedir que o entalhador continuasse fazendo obras de marcenaria, alegando que o seu ofício apenas lhe concedia a competência de executar trabalhos em talha, oratórios, retábulos, lanternas. 
Maria Aparecida de Menezes Borrego \& Rogério Ricciluca Matiello Félix

Ambientes domésticos e dinâmicas sociais em São Paulo colonial

neiro, nas primeiras décadas do século XIX, chama a atenção sobre a recorrência do critério da cor no mundo dos ofícios e a tentativa de conservação da ordem do Antigo Regime, através do emprego das noções de hierarquia e honra. ${ }^{103}$ Por outro lado, evidencia que, na América portuguesa, as relações sociais e de trabalho pautadas na lógica e na prática escravista impediam que os regulamentos das corporações de ofícios portuguesas fossem aqui aplicados na íntegra, devendo ajustar-se à realidade socioeconômica brasileira.

É o que também mostra José Newton Coelho Meneses no tocante à ritualização do processo de exame e de autorização para a atividade mecânica nas minas setecentistas, que exigia paradoxalmente o juramento público do escravo artesão para o exercício do ofício. ${ }^{104}$

Para a realidade paulistana, a análise dos inventários não só verificou que os agentes mercantis eram médios e grandes proprietários de escravos, ${ }^{105}$ como também que muitos cativos desempenhavam os ofícios mecânicos, como os três africanos que trabalhavam para o marceneiro João da Motta Liver. ${ }^{106}$ Por seu inventário, temos conhecimento de que, ao falecer em 1771, o marceneiro tinha em sua oficina, "duas poltronas de madeira vapuã por acabar as armações e sem assentos" (...) [e] duas canastras de cedro por encourar sem engonços nem fechaduras", que certamente seriam finalizadas pelos escravos João, Mateus e Paulo.

Para além dos pontos assinalados, o que os estudos e documentos mostram é que, ainda que houvesse transposição de peças de mobiliário da metrópole para a colônia, no século XVIII já se produzia móvel na América portuguesa em grande quantidade, não apenas de aspecto tosco, destinado ao uso cotidiano, mas também aquele de caráter simbólico, associado ao luxo e à ostentação, como bem detectara Robert Smith quando discorreu

\footnotetext{
${ }^{105}$ MARTINS, Monica de Souza. Entre a cruz e o capital: as corporações de ofícios no Rio de Janeiro após a chegada da família real (1808-1824). Rio de Janeiro: Garamond, Prefeitura do Rio de Janeiro, 2009. ${ }^{104}$ MENESES, José Newton Coelho. Artes fabris \& ofícios banais: o controle dos ofícios mecânicos pelas câmaras de Lisboa e das vilas de Minas Gerais (1750-1808). Belo Horizonte: Fino Traço, 2013.

${ }^{105}$ BORREGO, Maria Aparecida de Menezes. A teia mercantil, op. cit., 2010 (especialmente capítulo 4).

${ }^{106}$ No inventário aberto em 1771, localizamos “hum escravo por nome Joam solteiro de nasçam Rebollo de idade de sincoenta annos com os pes emxados de erisipella oficial de marceneyro (...) hum escravo por nome Mattheos de nasçam Banguella de idade de trinta e seis annos official de marceneiro cazado com Maria (...) hum escravo por nome Paulo de nasçam Banguella solteyro de idade de vinte e seis annos oficial de marceneyro". Apesp. Inventários e testamentos - C00654 - 1771.
} 
Maria Aparecida de Menezes Borrego \& Rogério Ricciluca Matiello Félix

Ambientes domésticos e dinâmicas sociais em Sc̃o Paulo colonial

sobre a importância e a qualidade artística do mobiliário produzido no período colonial brasileiro. ${ }^{107}$

A Bahia, em especial, exportou móveis, além de prataria e esculturas, para várias regiões brasileiras e para alguns lugares da América espanhola, especialmente a região do Prata. Segundo Flexor, num único carregamento saído de Salvador, em 1797, para todos os portos do continente americano de barra-fora constavam "4 mesas de vinhático, 5 camas de vento, 2 coxos de banho, 110 cadeiras de couro, 5 cadeiras de arruar, 1 caixa de vinhático, 1 cômoda do dito". ${ }^{108}$

Se não sabemos o destino desses móveis da Bahia, sobretudo os de jacarandá, certamente muitos iriam - ou foram anteriormente - para São Paulo, pois nas descrições de móveis de assento, de suporte e de repouso encontramos a menção "feito na Bahia", o que mais uma vez confirma a circulação de bens domésticos na América portuguesa e a articulação da cidade de São Paulo a outras regiões, não só como abastecedora de gêneros alimentares e de fazenda seca, mas como importadora de peças de mobiliário.

\section{À guisa de conclusão}

Na introdução do livro Gender, taste and material culture in Britain and North America, 1700-1830, os organizadores John Styles e Amanda Vickery comentaram que o grande problema, principalmente entre os historiadores sociais e econômicos do consumo do século XVIII britânico, é a pouca consideração dada à materialidade dos objetos que se propõem a estudar. Segundo eles, como os estudos se reduzem a contar os bens que aparecem em inventários, embora ajudem a mapear a difusão de novos produtos, deixam de lado a materialidade dos objetos reais e com ela nossa habilidade para compreender os objetos como artefatos. ${ }^{109}$

Neste artigo, procuramos justamente atentar para as características materiais das peças de mobiliário, focalizando pormenores de assentos, espaldares, encostos, pés, gavetas, travessas, pilares, torneados, revestimentos e

\footnotetext{
${ }^{107}$ SMITH, Robert. Igrejas, casas e móveis. Aspectos da arte colonial brasileira. Recife: Universidade Federal de Pernambuco, 1979, apud BRANDÃO, Angela, op. cit., 2009, p. 47-8.

${ }^{108}$ FLEXOR, Maria Helena, op. cit., 2009, p. 84.

${ }^{109}$ STYLES, John \& VICKERY, Amanda (org.). Gender, taste and material culture in Britain and North America, 1700-1830. New Haven; Londres: Yale Center of British Art; Paul Mellon Centre for Studies of British Art, 2006.
} 
Maria Aparecida de Menezes Borrego \& Rogério Ricciluca Matiello Félix

Ambientes domésticos e dinâmicas sociais em São Paulo colonial

suas respectivas matérias-primas, para refletir sobre os interiores domésticos e as dinâmicas sociais que se desenvolviam intra e extramuros.

Assim como seus congêneres no reino e em outros espaços coloniais, em meados do século XVIII, esses homens passaram a ter acesso a um conjunto de bens antes pouco habituais, ${ }^{110}$ como determinados tipos de móveis que se estavam confeccionando naquele contexto.

Ao rechear seus domicílios com peças novas e mais numerosas, transformaram-nas em espaços de maior convívio social - dado o número elevado de móveis de assento -, dispondo de peças de aparato - bufetes de quatro gavetas e leitos - eventualmente importadas, e investindo em conforto e ostentação, que bem se ilustra pela ocorrência de delicados cortinados de dosséis e preguiceiros profusamente ornamentados. Ademais, os usos sociais desses móveis indicam que os setores ligados à lide mercantil, em especial os mais abastados, estavam em sintonia com o que se produzia em outras áreas coloniais e estrangeiras, e suas residências são a prova de que a cidade de São Paulo estava articulada ao Império português por meio da circulação e consumo de artefatos domésticos.

\section{Referências bibliográficas}

\section{Documentação primária}

\section{Manuscrita}

Agostinho Duarte do Rego

Alexandre Monteiro de Sampaio

Ana de Oliveira Montes

Ana Francisca Novaes

Ana Maria de Assumpção

André Alvares de Castro

Aniceto Fernandes

Antônio Barbosa de Lima

Antônio da Costa Rodrigues

Antônio José Vaz

Antônio José Vieira Barbosa

Antônio Ribeiro Pires e Maria Rodrigues Barbosa

Antônio Rodrigues Froes

Bartolomeu Bueno Cacunda

$\begin{array}{rr}\text { Arquivo do Estado de São Paulo. Inventários e testamentos } \\ 1752 & \text { C00528 } \\ 1755 & \text { C00703 } \\ 1765 & \text { C00664 } \\ 1805 & 201007000449-1090 \\ 1806 & 201006003837-1587 \\ 1752 & \text { C00721 } \\ 1762 & C 00540 \\ 1764 & C 00631 \\ 1773 & \text { C00631 } \\ 1825 & 201006003973-1203 \\ 1831 & 201006003416-1091 \\ 1760 & C 00634 \\ 1756 & C 00634 \\ 1750 & C 00707\end{array}$

\footnotetext{
${ }^{110}$ PEDREIRA, Jorge Miguel. Os homens da praça de Lisboa de Pombal ao Vintismo (1755-1822). Tese de doutorado em História, Universidade Nova de Lisboa, Lisboa, 1995; MADUREIRA, Nuno, op. cit., 1992; FRAGOSO, João Luís; SAMPAIO, Antônio Carlos Jucá de; ALMEIDA, Carla (org.). Conquistadores e negociantes: história das elites no Antigo Regime nos trópicos. Rio de Janeiro: Civilização Brasileira, 2007.
} 
rev. hist. (São Paulo), n. 175, p. 91-132, jul.dez., 2016 http://dx.doi.org/10.11606/issn.2316-9141.rh.2016.123851
Maria Aparecida de Menezes Borrego \& Rogério Ricciluca Matiello Félix

Ambientes domésticos e dinâmicas sociais em São Paulo colonial
Bartolomeu Correa Bueno

Bento de Oliveira Lima

Bento Dias Vieira

Bento do Amaral da Silva

Caterina Mendes Tenória

Cornélio Rodrigues Arzão

Diogo de Toledo Lara

Diogo José da Silva

Diogo José de Souza

Domingos Barreto de Lima

Domingos Fernandes Lima

Domingos João Vilarinhos

Domingos Lobo de Oliveira

Escolástica Veloso

Francisco Afonso Lima

Francisco Coelho Aires

Francisco da Silva Coelho

Francisco Duarte do Rego

Francisco Leandro Leme de Moraes

Francisco Pereira Mendes

Francisco Pinheiro de Sepeda

Gaspar de Matos

Genebra de Barros Leite

Inácia Maria Rodrigues

Inácio Soares de Barros

Izidora do Amaral

João da Mota Liver

João do Prado de Siqueira

João Francisco Lustosa

João José de Alvarenga

João Pinto Rodrigues

João Rodrigues Vaz

Joaquim Dias Vieira

Joaquim José dos Santos

Joaquim Mariano Galvão de Moura Lacerda

José Barbosa de Lima

José Casado Vilas Boas

José da Costa Vale

José da Silva Ferrão

José da Silva Góes

José de Lemos e Moraes

José do Prado da Cunha

José Pinto Tavares

José Pires de Almeida

José Rodrigues Pereira

José Vaz de Carvalho

Juliana Maciel

Luís Rodrigues Lisboa

Manoel Cardoso de Abreu

Manoel de Gois Cardoso e Isabel de Almeida

Manoel de Macedo

Manoel Francisco Domingues

Manoel Gonçalves Sete

Manoel José da Cunha

Manoel Luís da Costa

Manoel Mendes de Almeida

Manoel Pedroso Oliveira

Manoel Rodrigues Ferreira

Manoel Veloso
1753

1769

1823

1753

1747

1750

1743

1824

1811

1756

1812

1766

1750

1753

1756

1776

1750

1782

1837

1781

1760

1735

1838

1768

1759

1750

1771

1742

1746

1836

1761

1746

1835

1828

1834

1755

1749

1780

1762

1748

1744

1749

1815

1771

1770

1825

1754

1761

1804

1744

1753

1771

1755

1746

1755

1756

1742

1768

1752
$\mathrm{C00707}$

$\mathrm{C00668}$

201007000202 - 470

$\mathrm{C} 00645$

$\mathrm{C} 00658$

$\mathrm{C} 00658$

$\mathrm{C} 00643$

$201006003981-1185$

201007000516 - 1894

C00643

201006003305 - 1895

C00544

C00643

$\mathrm{C} 00530$

C00690

$\mathrm{C00640}$

$\mathrm{C} 00523$

$\mathrm{C} 00726$

201007000188 - 285

C00664

C00690

$\mathrm{C} 00734$

$201007000804-531$

C00546

$\mathrm{C} 00670$

C00670

C00654

$\mathrm{C} 00733$

C00667

$201007000260-548$

C00620

C00659 + avulso

201006003486 - 307

201006004032 - 472

$\mathrm{C} 00623$

$\mathrm{C} 00686$

$\mathrm{C} 00707$

$\mathrm{C} 00674$

C00541

C00659

$\mathrm{C} 00658$

C00519

$201007000466-1169$

C00737

$\mathrm{C} 00686$

201006003982 - 981

$\mathrm{C} 00623$

C00538

$201007000351-1631$

C00623

C00531 e 705

C00652

$\mathrm{C} 00653$

C00651

$\mathrm{C} 00703$

C00532

C00623

$\mathrm{C} 00665$

C00528 
Maria Aparecida de Menezes Borrego \& Rogério Ricciluca Matiello Félix

Ambientes domésticos e dinâmicas sociais em São Paulo colonial
Manuel Rodrigues Jordão (alferes)

Marcos Francisco

Maria Francisca Lustosa

Maria Josefa Mendes da Silva

Matias de Castro de Oliveira

Matias de Oliveira Lobo

Mecia de Aguirra de Camargo

Modesto Antônio Coelho Neto

Nicolau Francisco Rosal

Pedro da Silva Pontes

Pulqueria Maria de Barros

Rosa Maria do Rozario Pedrosa

Vicente Ferreira Neves

1786
1758
1758
1806
1757
1745
1753
1803
1751
1763
1837
1803
1766

Arquivo do Tribunal de Justiça do Estado de São Paulo. Inventários e testamentos Manuel Rodrigues Jordão (brigadeiro): Inventários do $1^{\circ}$ cartório de família, proc. 229-1828.

Luís Antônio de Souza Queiroz (brigadeiro): Inventários do $1^{\circ}$ cartório de família, proc. 530-1819.

\section{Impressa}

BLUTEAU, Raphael. Vocabulario portuguez \& latino: aulico, anatomico, architectonico... Coimbra: Collegio das Artes da Companhia de Jesus, 1712-1728, 10 vol.

DEBRET, Jean Baptiste. Voyage pittoresque et historique au Brésil. Paris: Firmin Didot Frères, 1835. Disponível em: http://www.brasiliana.usp.br/bbd/handle/1918/624520069.

Documentos interessantes para a história e costumes de S. Paulo, vol. 62. São Paulo: Instituto Historico e Geographico de S. Paulo, 1937.

LUCCOCK, John. Notas sobre o Rio de Janeiro e partes meridionais do Brasil (1808-1818). São Paulo, Belo Horizonte: Edusp/ Itatiaia Editora, 1975.

MORAES SILVA, Antônio de. Diccionario da língua portuguesa. Lisboa: Officina de Simão Thaddeo Ferreira, 1789.

Registo Geral da Camara Municipal de S. Paulo 1735-1742, vol. V. São Paulo: Typographia Piratininga, 1918, p. 462-465.

SAINT-HILAIRE, Auguste de. Viagem ao Rio Grande do Sul (1820-1821). São Paulo, Belo Horizonte: Edusp/ Itatiaia Editora, 1974.

SPIX, Johann Baptiste von $\&$ MARTIUS, Carl Friedrich Philippe von. Viagem pelo Brasil (1818-1819), vol. II. Rio de Janeiro: Imprensa Nacional, 1938. 


\section{Livros, revistas e teses}

ABREU, Jean Luiz Neves de. $O$ imaginário do milagre e a religiosidade popular: um estudo sobre a prática votiva nas Minas do século XVIII. Dissertação de mestrado em História, Faculdade de Filosofia e Ciências Humanas, Universidade Federal de Minas Gerais, Belo Horizonte, 2001.

ABREU, Jean Luiz Neves. Difusão, produção e consumo das imagens visuais: o caso dos ex-votos mineiros do século XVIII. Revista Brasileira de História, vol. 25, n. 49, São Paulo, 2005.

ALGRANTI, Leila Mezan. Famílias e vida doméstica. In: SOUZA, Laura de Mello e (org.). História da vida privada no Brasil, vol. 1. São Paulo: Companhia das Letras, 1997.

ARAÚJO, Jeaneth Xavier. Os artífices do sagrado e a arte religiosa nas minas setecentistas: trabalho e vida cotidiana. São Paulo: Annablume, 2013.

BACELLAR, Carlos de Almeida Prado. Viver e sobreviver em uma vila colonial - Sorocaba, séculos XVIII e XIX. São Paulo: Annablume/Fapesp, 2001.

BORREGO, Maria Aparecida de Menezes. A teia mercantil: negócios e poderes em São Paulo colonial (1711-1765). São Paulo: Alameda/ Fapesp, 2010.

. Laços familiares e aspectos materiais da dinâmica mercantil na cidade de São Paulo (séculos XVIII e XIX). Anais do Museu Paulista, vol. 18, n. 1, História e cultura material, São Paulo 2010, p. 11-41.

BRANDÃO, Angela. Anotações para uma história do mobiliário brasileiro do século XVIII. Revista CPC (USP), vol. 9, 2009-2010, p. 42-64.

. Das pontes aos castiçais: a produção de mobiliário artístico em Minas Gerais do século XVIII e os ofícios mecânicos. Revista Científica, vol. 4. Curitiba: FAP, 2009, p. 50-66.

BRUNO, Ernani da Silva. O equipamento da casa bandeirista segundo os antigos inventários e testamentos. São Paulo: Departamento do Patrimônio Histórico, 1977.

CANTI, Tilde. O móvel no Brasil: origens, evolução e características. Rio de Janeiro: Ed. Candido Guinle de Paula Machado, 1980.

CARVALHO, Vânia Carneiro de. Gênero e artefato: o sistema doméstico na perspectiva da cultura material: São Paulo, 1870-1920. São Paulo: Edusp, 2008.

CASTRO, Marcia de Moura. Ex-votos mineiros: as Tábuas votivas no ciclo do ouro. Belo Horizonte: Expressão e Cultura, 1994.

DEL PRIORE, Mary. Histórias íntimas: sexualidade e erotismo na história do Brasil. São Paulo: Planeta, 2011.

DURÃES, Andreia. Grupos intermédios em Portugal (1600-1850): uma aproximação ao vocabulário social. Topoi, vol. 14, n. 27, Rio de Janeiro, 2013, p. 318-343.

FERNANDES, Antônia Terra de Calazans. Memórias de ofício. Tese de doutorado em História Social, Faculdade de Filosofia, Letras e Ciências Humanas, Universidade de São Paulo, São Paulo, 1997.

FIGUEIREDO, Beatriz Helena Ramsthaler. Os ex-votos do período colonial: uma forma de comunicação entre pessoas e santos (1720-1780). Dissertação de mestrado em História, Pontifícia Universidade Católica, São Paulo, 2010. 
Maria Aparecida de Menezes Borrego \& Rogério Ricciluca Matiello Félix

Ambientes domésticos e dinâmicas sociais em São Paulo colonial

FLEXOR, Maria Helena Ochi. Mobiliário baiano. Brasília, DF: Iphan / Programa Monumenta, 2009.

Ofícios, manufaturas e comércio. In: SZMRECSÁNYI, Tamás (org). História econômica do período colonial. São Paulo: Hucitec, 2002.

FRAGOSO, João Luís; SAMPAIO, Antônio Carlos Jucá de; ALMEIDA, Carla (org.). Conquistadores e negociantes: história das elites no Antigo Regime nos trópicos. Rio de Janeiro: Civilização Brasileira, 2007.

FRANCO, Carlos. O mobiliário das elites de Lisboa na segunda metade do século XVIII. Lisboa: Livros Horizonte, 2007.

O quarto de dormir e as artes decorativas em Lisboa. In: SOUSA, Gonçalo Vasconcelos e (org.). Matrizes para investigação das artes decorativas. Porto: Citar, 2010.

FREIRE, Fernanda Castro. Mobiliário, vol. 1. Lisboa: Fundação Ricardo do Espírito Santo Silva, 1994.

GINZBURG, Carlo. Sinais: Raízes de um paradigma indiciário. In: Idem. Mitos, emblemas, sinais: morfologia e história. São Paulo: Companhia das Letras, 1989, p. 143-179.

GOODMAN, Dena. The secrétaire and the integration of the eighteenth-century self. In: GOODMAN, Dena \& NORBERG, Kathryn (org.). Furnishing the eighteenth century: what furniture can tell us about European and American past. Nova York; Londres: Routledge, 2007, p. 183-204.

HAMEISTER, Martha Daisson. O continente do Rio Grande de São Pedro: os homens, suas redes de relações e suas mercadorias semoventes (c. 1727-c. 1763). Dissertação de mestrado em História, Universidade Federal do Rio de Janeiro, Rio de Janeiro, 2002.

HELLMAN, Mimi. Furniture, sociability, and the work of leisure in eighteenthcentury France. Eighteenth-century Studies. vol. 32, n. 4, 1999, p.415-445.

HOLANDA, Sérgio Buarque de. Monções e Capítulos da expansão paulista. Organização de Laura de Mello e Souza e André Sekkel de Cerqueira. Notas de André Sekkel de Cerqueira. São Paulo: Companhia das Letras, 2014.

LEMOS, Carlos Alberto. Casa paulista: história das moradias anteriores ao ecletismo trazido pelo café. São Paulo: Edusp, 1999.

MACHADO, Alcântara. Vida e morte do bandeirante. Belo Horizonte: Itatiaia; São Paulo: Edusp, 1980.

MADUREIRA, Nuno Luís. Cidade: espaço e quotidiano. Lisboa 1740-1830. Lisboa: Livros Horizonte, 1992. Luxo e distinção: 1750-1830. Lisboa: Editorial Fragmentos, 1990.

MARCíliO, Maria Luiza. A cidade de São Paulo. Povoamento e população. 1750-1850. São Paulo: Pioneira/Edusp, 1974.

Crescimento demográfico e evolução agrária paulista - 1700-1836. São Paulo: Hucitec/Edusp, 2000.

MARCONDES, Renato Leite. Formação da rede regional de abastecimento do Rio de Janeiro: a presença dos negociantes de gado (1801-1811). Topoi, Rio de Janeiro, mar. 2001, p. 41-71. 
MARINS, Paulo Cesar Garcez. Vida cotidiana entre os paulistas: moradias, alimentação, indumentária. In: SETUBAL, Maria Alice (org.). Terra paulista: histórias, arte, costumes. São Paulo: C. Imesp, 2004.

MARTINEZ, Cláudia Eliane Parreiras Marques. A natureza dentro da casa paulista. In: MARTINEZ, Paulo Henrique (org.). História ambiental paulista: temas, fontes e métodos, vol. 1. São Paulo: Senac, 2007, p. 51-69.

MARTINS, Monica de Souza. Entre a cruz e o capital: as corporações de ofícios no Rio de Janeiro após a chegada da família real (1808-1824). Rio de Janeiro: Garamond, Prefeitura do Rio de Janeiro, 2009.

MAYUMI, Lia. Taipa, canela-preta e concreto. São Paulo: Romano Guerra Editora, 2008.

MENESES, José Newton Coelho. Artes fabris $\mathcal{E}$ ofícios banais: o controle dos ofícios mecânicos pelas câmaras de Lisboa e das vilas de Minas Gerais (1750-1808). Belo Horizonte: Fino Traço, 2013.

MENESES, Ulpiano Toledo Bezerra de. A cultura material no estudo das sociedades antigas. Revista de História, n. 115, São Paulo, 1983, p.103-117.

Fontes textuais, cultura visual, história visual. Balanço provisório, propostas cautelares. Revista Brasileira de História, vol. 23, n. 45, São Paulo, 2003, p. 11-36.

Rumo a uma "história visual". In: MARTINS, José de Souza; ECKERT, Cornelia; NOVAES, Sylvia Caiuby. O imaginário e o poético nas Ciências Sociais. Bragança Paulista: Edusc, 2005, p. 33-56.

MONTEIRO, Nuno Gonçalo; CARDIM, Pedro; CUNHA, Mafalda Soares da. Optima pars: elites ibero-americanas do Antigo Regime. Lisboa: ICS, 2005.

OLIVAL, Fernanda. As ordens militares e o Estado Moderno: honra, mercê e venalidade em Portugal (1641-1789). Lisboa: Estar, 2001.

Os lugares e espaços do privado nos grupos populares e intermédios. In: MONTEIRO, Nuno Gonçalo. História da vida privada em Portugal, vol. 2. Lisboa: Círculo de Leitores, 2011.

OSORIO, Helen. O Império português no Sul da América: estancieiros, lavradores e comerciantes. Porto Alegre: Editora da UFRGS, 2007.

PAIXÃO, Giselle Marques Leite. Sistema descritivo para acervos de mobiliário, contendo 923 vocábulos e 638 ilustrações. BARBUY, Heloisa (org.). Instrumento para catalogação produzido para o Serviço de Objetos do Museu Paulista-USP. São Paulo: MP-USP, 1999.

PEDREIRA, Jorge Miguel. Os homens da praça de Lisboa de Pombal ao Vintismo (1755-1822). Tese de doutorado em História, Universidade Nova de Lisboa, Lisboa, 1995.

PEREZ SAMPER, María de los Ángeles. Espacios e prácticas de sociabilidad en el siglo XVIII: tertulias, refrescos y cafés de Barcelona. Cuadernos de Historia Moderna, n. 26, 2001, p. 11-55.

PINTO, Augusto Cardoso \& NASCIMENTO, João Felipe da Silva. Cadeiras portuguesas. Lisboa: Ed. dos autores, 1952.

PINTO, Pedro da Costa. O móvel de assento português do século XVIII. Lisboa: Mediatexto, 2005.

POLLETI, Daniel Nogueira. Relatório de Iniciação - Fapesp, 2011. 
Maria Aparecida de Menezes Borrego \& Rogério Ricciluca Matiello Félix

Ambientes domésticos e dinâmicas sociais em São Paulo colonial

RABELLO, Elizabeth Darwiche. Os ofícios mecânicos e artesanais em São Paulo na segunda metade do século XVIII. Revista de História, n. 112, 1977, p. 575-588.

REIS FILHO, Nestor Goulart. O caminho do Anhanguera. São Paulo: Via das Artes, 2014.

RODRIGUES, José Wasth. Descrições de mobiliário. São Paulo: Museu Paulista, 1948. Datilografado e rubricado.

SANTOS, Noronha. Um litígio entre marceneiros e entalhadores no Rio de Janeiro. Revista do Sphan, $\mathrm{n}^{\circ}$ 06, 1942, p. 295-317.

SARGENTSON, Carolyn. Looking at furniture inside out: Strategies of secrecy and security in eighteenth-century French furniture. In: GOODMAN, Dena $\mathcal{E}$ NORBERG, Kathryn (org.). Furnishing the eighteenth century: what furniture can tell us about European and American past. Nova York; Londres: Routledge, 2007, p. 205-236.

SARMENTO, Therezinha de Moraes. Um preguiceiro no Museu Histórico Nacional. Anais do Museu Histórico Nacional, vol. XXI, 1969, p. 43-52.

SCARANO, Julita. Fé e milagre: Ex-votos pintados em madeiras - século XVIII e XIX. São Paulo: Edusp, 2004.

SMITH, Robert C. Pinturas de ex-votos existentes em Matosinhos e outros santuários portugueses. Matosinhos: Câmara Municipal de Matosinhos, 1966.

SOUZA, Laura de Mello e. O diabo e a Terra de Santa Cruz: feitiçaria e religiosidade popular no Brasil colonial. São Paulo: Companhia das Letras, 1986.

STYLES, John \& VICKERY, Amanda (org.). Gender, taste and material culture in Britain and North America, 1700-1830. New Haven; Londres: Yale Center of British Art; Paul Mellon Centre for Studies of British Art, 2006.

SUANO, Marlene. Alfaias, apetrechos, tarecos, trecos: os móveis. In: MENESES, Ulpiano T. Bezerra de(org.).Comoexplorarum museu histórico. São Paulo:Museu Paulista/USP, 1992.

TRINDADE, Jaelson Bitran. O fantasma de Debret. Revista de História. Rio de Janeiro: Biblioteca Nacional, 7 jan. 2008.

VAINFAS, Ronaldo. Moralidades brasílicas: deleites sexuais e linguagem erótica na sociedade escravista. In: SOUZA, Laura de Mello e (org.). História da vida privada no Brasil, vol. 1. São Paulo: Companhia das Letras, 1997, p. 221-273.

VICKERY, Amanda. An Englishman's home is his castle? Thereholds, boundaries and privacies in the eighteenth-century London house. Past and Present, 199, May 2008, p. 147-173.

His and hers. In: VICKERY, Amanda. Behind closed doors: At home in Georgian England. New Haven, Londres: Yale University Press, 2009, p. 106-128.

The gentleman's daughter: Women's lives in Georgian England. New Haven, Londres: Yale University Press, 2003.

Women and the world of goods: a Lancashire consumer and her possessions, 1751-81. In: BREWER, John \& PORTER, Roy. Consumption and the world of things. Londres: Routledge, 1994, p. 274-301.

WEATHERILL, Lorna. Consumer behaviour and material culture in Britain, 1660-1760. Londres; Nova York: Routledge, 1988. 